\title{
The principles, practices and some future applications of near infrared spectroscopy for predicting the nutritive value of foods for animals and humans
}

\author{
D. I. Givens', J. L. De Boever ${ }^{2}$ and E. R. Deaville ${ }^{1}$ \\ 'Feed Evaluation and Nutritional Sciences, ADAS Dairy Research Centre, Alcester Road, \\ Stratford-on-Avon, CV37 9RQ, UK. ${ }^{2}$ National Institute for Animal Nutrition-Centre for \\ Agricultural Research, Gent-Scheldeweg 68, B-9090 Melle-Gontrode, Belgium
}

\begin{abstract}
The current application and future potential of near infrared (NIR) spectroscopy in the evaluation of foods for domesticated animals and humans is enormous. Where used, NIR spectroscopy has revolutionized the analysis and nutritional evaluation of animal feeds and human foods by providing a rapid means of examination. The availability of accurate and rapid methods of evaluation is becoming increasingly important to meet the nutritional requirements of animals for meat, milk, wool and egg production. This is essential for efficient and economic animal production, to maintain animal health and to minimize environmental impact. Accurate evaluation methods are also needed in relation to national and international legislation that regulates the circulation, trade and inspection of foods and feeds, aids effective functioning of the market and guards the safety of animals and humans. The aim of this review is to outline the theory and principles of NIR spectroscopy and to focus primarily on its application in the field of animal nutrition. The vital role NIR spectroscopy is playing in the prediction of biologically meaningful feed characteristics, including data derived in vivo, is demonstrated particularly through its application to forage evaluation, but also in the examination of raw materials and compound feeds. While the applications of NIR spectroscopy to different foods and drinks are extensive, this review gives an overview only of selected reported applications including its use for predicting nutritive value (mainly water, protein, fat, sucrose and starch content), monitoring food processing and for food authentication. The review provides clear evidence that the future application of NIR spectroscopy will undoubtedly increase, playing a vital role in the authentication of the quality and origin of foods and feeds and enabling the complex methods of feed evaluation required in the future to be put into widespread use.
\end{abstract}

\section{Introduction}

An accurate evaluation of foods for domesticated animals and humans is becoming increasingly important for several reasons. The selection of animals with high production potential requires an adequate supply of nutrients. This is essential not only for the health of the animals, but also from an economic viewpoint. Feed cost is the single most important cost of animal production 
systems (De Boer \& Bickel, 1988) and largely determines financial return to the farmer. Moreover, the growing awareness of the impact of animal production systems on the environment stresses the need for a balanced diet. The amount of feed and its composition significantly affect the performance of the animal with respect to milk, meat, wool and egg production and their composition, as well as the output of wastes (Dijkstra, 1993). The nutrition of humans not only aims to meet requirements and to assure good health, but also to prevent diseases and to slow down the ageing process (Debry, 1992). Accurate evaluation methods are also needed in relation to national and international legislation regulating the circulation, trade and inspection of food and feeds, aiming at an effective functioning of the market and guarding the safety of animals and humans.

The value of a feed, in terms of animal production potential, can be defined as the result of the intake of digestible energy and the efficiency of utilization, assuming that toxic factors are absent and no essential element is in short supply (Hacker, 1981). The feeding value, classically expressed in energy and protein units, is derived from wet chemical analyses and from feeding trials using animals of the type for which the feed is intended. In vivo experiments are tedious, time consuming and expensive and only feasible in scientific institutes. For feed evaluation to remain practical on a large scale, research has developed regression equations to predict in vivo data based on chemical parameters and/or more convenient in vitro techniques using living microorganisms or commercial enzymes (MAFF, 1993; Weisbjerg \& Hvelplund, 1993; De Boever et al. 1994a,b; Giger-Reverdin, 1994; Noblet et al. 1994). Although this approach is a reasonable compromise between simplicity and accuracy of prediction, a period of several days is still required before data become available. Near infrared (NIR) spectroscopy can now provide most of this information in a matter of seconds.

Apart from its rapidity, NIR spectroscopy offers a number of other important advantages over traditional chemical methods. It is a physical, nondestructive method, requiring minimal or no sample preparation, and its precision is high. In contrast with traditional chemical analysis no reagents are required and no wastes are produced. It is a multi-analytical technique: several determinations can be made simultaneously. Once calibrated, the NIR spectrometer is simple to use and operate. The chief disadvantages are the need for high precision spectroscopic instruments, dependence on time consuming and laborious calibration procedures, complexity in the choice of data treatment and lack of sensitivity for minor constituents (Norris, 1989). Another limitation may be the transfer of calibrations due to optic differences between instruments.

The study of the NIR region of the spectrum is not new. In 1800, Herschel first observed radiation beyond the red portion of the visible spectrum, which could be detected by means of a photographic plate. Interest in the 'photographic' IR during the first half of the twentieth century was still apparent but most attention was devoted to the mid infrared. Research into communications during the Second World War led to the development of the photoelectric detector for the NIR region and therefore the possibility of building NIR spectrophotometers. In the 1950s, K. Norris of the United States Department of Agriculture (USDA) began to investigate optical properties of dense, light scattering biological materials (Norris \& Butler, 1961). His initial work in NIR spectroscopy involved transmittance through carbon tetrachloride or methanol extracts or slurries to measure moisture in grains and seeds (Norris \& Hart, 1965) or through thin layers of samples such as meat for measuring moisture and fat (Ben-Gera \& Norris, 1968). The real breakthrough came by his efforts to develop a grain moisture meter, when he solved the problems due to scattering and interference of other constituents by using reflectance spectroscopy and multiple regression techniques for calibration (Norris, 1992). The first applications were in the grain industry. The studies of Williams 
(1975) and Hunt et al. (1977) led to the adoption of NIR spectroscopy as an official protein testing method for wheat marketing in Canada and the USA respectively. Norris et al. (1976) showed that the technique could be applied for predicting the composition (protein and fibre), intake and digestibility of forages by sheep. This was the basis for establishing a spectrocomputer system for forage research at the USDA's Regional Pasture Research Laboratory in collaboration with the Pennsylvania State University. Under the supervision of J. Shenk a reflectance monochromator and software to collect, store and process NIR data were designed.

Prompted by the formation of a USA network of forage laboratories in 1978, the software was further adapted for public use and made available for use abroad. By that time applications included the nutritive value of feed grains, forages, forage rations and mixed grains, identification of feedstuffs, heat-damaged protein in dehydrated lucern (alfalfa) and mineral analyses (Shenk et al. 1979). Up to 1978, only instruments with specific filter sets for either grainsoyabeans or forages were on the market (Dickey/John, Technicon and Neotec). The impetus to extend the fields of application along with the advent of the personal computer lead to the commercial availability of instruments with more wavelength (scanning (tilting) filter, monochromator) and data processing capabilities. As a result, the number of research publications on the use of NIR spectroscopy in feed and food analysis increased rapidly. By 1979, Norris's continuing research had led to the practical development of NIR transmittance spectroscopy of intact cereal grains (Norris \& Williams, 1979). During this time progress was limited by computing power and rapid progress has followed the advent of powerful desk top personal computers in the 1980s. Nowadays, analysis of even undried and unmilled forages is possible by using a large moving sample cell (Shenk, 1992). Eliminating the need for sample grinding also opened the way for on-line analysis. The introduction of fibre optics contributed to an enormous expansion of conventional NIR spectroscopy for remote measurements, for example, for products that are difficult to handle (e.g. fruits, vegetables, meat, fish) and for monitoring fermentation processes (Bertrand et al. 1992). This progress is at present furthered by the development of new rapid-scan NIR monochromator/detection systems without mechanically moving parts, such as acousto-optic tunable filters, diode arrays or charge-coupled devices (Eschenauer et al. 1992). The accompanying miniaturization of spectrometers makes them powerful analytical tools where robust systems in hostile environments are required. Developments in chemometrics (see p.7) have led to new data treatments and calibration algorithms. Besides the traditional multiple linear regression technique, Fourier transforms, full spectrum and non-linear models are used. Another expanding field is the use of NIR spectroscopy for qualitative purposes including quality control. Thus, as well as providing quantitation of major nutrients, NIR can also distinguish types of feeds or foods (e.g. it could identify different varieties of rice).

This review will concentrate on the use of NIR spectroscopy in the field of animal nutrition although some aspects of its use with human food will be covered for completeness.

\section{Theory and principles}

For a comprehensive and detailed account of NIR spectroscopy theory, the reader is referred to the books of Osborne \& Fearn (1986) and Williams \& Norris (1990). Spectroscopy literally means looking at light and is based on the interaction of electromagnetic radiation with the matter to be analysed. The main regions of the IR spectrum are given in Table 1.

Near infrared light is defined as the wavelength region from 730 to $2500 \mathrm{~nm}$, lying between the visible light with shorter wavelengths and the infrared light with longer wavelengths. Mid 
Table 1. Divisions of the infrared region (Osborne \& Fearn, 1986)

\begin{tabular}{llcc}
\hline Region & Characteristic transition & $\begin{array}{c}\text { Wavelength } \\
\text { range }(\mathrm{nm})\end{array}$ & $\begin{array}{c}\text { Wavenumber } \\
\text { range }\left(\mathrm{cm}^{-1}\right)\end{array}$ \\
\hline $\begin{array}{l}\text { Near infrared } \\
\text { Middle infrared }\end{array}$ & Overtones/combinations & $730-2500$ & $14300-40000$ \\
Far infrared & Fundamental vibrations & $2500-5 \times 10^{4}$ & $4000-200$ \\
\hline
\end{tabular}

infrared radiation (2500-50000 $\mathrm{nm}$ ) provides energy quanta causing changes in the vibrational energy states of the molecules. When a sample is irradiated, light is absorbed selectively according to the specific vibration frequencies of the molecules present and gives rise to a spectrum. Mid infrared spectra of foods may consist of sharp absorption bands, from which organic compounds may be identified, but are less suited for quantitative analysis because of the low signal to noise ratio of the instruments. The NIR region is characterized by overtone and combination bands of fundamental vibrations occurring in the mid infrared. These arise due to the anharmonic nature of molecular vibrations. All organic bonds have absorption bands in the NIR region, whereas minerals may only be detected in organic complexes and chelates or indirectly by their effect on hydrogen bonds (Shenk et al. 1992). Because of the light mass of the hydrogen atom, overtones and combination bands of hydrogen bearing functional groups ( $\mathrm{C}-\mathrm{H}, \mathrm{O}-\mathrm{H}$ and $\mathrm{N}-\mathrm{H}$ ) dominate the NIR spectra of feeds. These show broad and overlapping bands less suited for structural studies and microanalysis, the sensitivity limit being about $0.15 \%$ for most constituents (Iwamoto \& Kawano, 1992). On the other hand, the NIR region offers some advantages for quantitative analysis of major elements. NIR instruments have a very high signal to noise ratio, which is typically $10000: 1$. The spectral information is repeated through the successive overtones and combination tones, the intensity of the bands involved becoming each time weaker by an order of magnitude towards shorter wavelengths. These lowered intensities in the NIR region mean that solid samples do not need to be diluted for diffuse reflectance measurements and non-linearity effects due to strong absorptions are less likely to occur.

When monochromatic radiation interacts with a sample, it may be absorbed, transmitted or reflected (Fig. 1). According to the Beer-Lambert law, the concentration of an absorber (c) is directly proportional to the sample absorbance $(\mathrm{A}): \mathrm{c}=\mathrm{A} / \mathrm{e} . \mathrm{l}$, where $\mathrm{e}$ is the molar absorptivity and $\mathrm{I}$ is the path length. This relationship is fundamental to quantitative absorption spectroscopy and it may be applied not only to transmission measurements, but also to the diffuse reflectance of light scattering materials. The main difference is that the path length of radiation, which is maintained constant in absorption spectroscopy, is affected by light scattering. Scattering occurs when radiation transmitted through the surface and emerging after partial absorption is diffused by random reflections, refractions and diffractions at further interfaces inside the sample or undergoes further transmittance and absorption at other interfaces. Diffuse reflectance, most commonly used, is applied for particulate material in the wavelength range from 1100 to $2500 \mathrm{~nm}$, whereas transmittance is more commonly measured from 800 to $1100 \mathrm{~nm}$. Scattering depends on the physical properties of the sample, the most important of which are particle size, moisture content and temperature. The relationship between concentration and absorbed energy is further disturbed by overlapping of spectral bands from different constituents present in the sample (Fig. 2). As there is no mathematical law to describe the interaction of radiation with a scattering medium containing a heterogeneous distribution of absorbing species, NIR is an empirical or secondary technique requiring calibration using 
(a) = Specular Reflectance

(b) = Diffuse Reflectance

(c) = Absorption

(d) = Transmittance

$(e)=$ Refraction

(f) $=$ Scattering

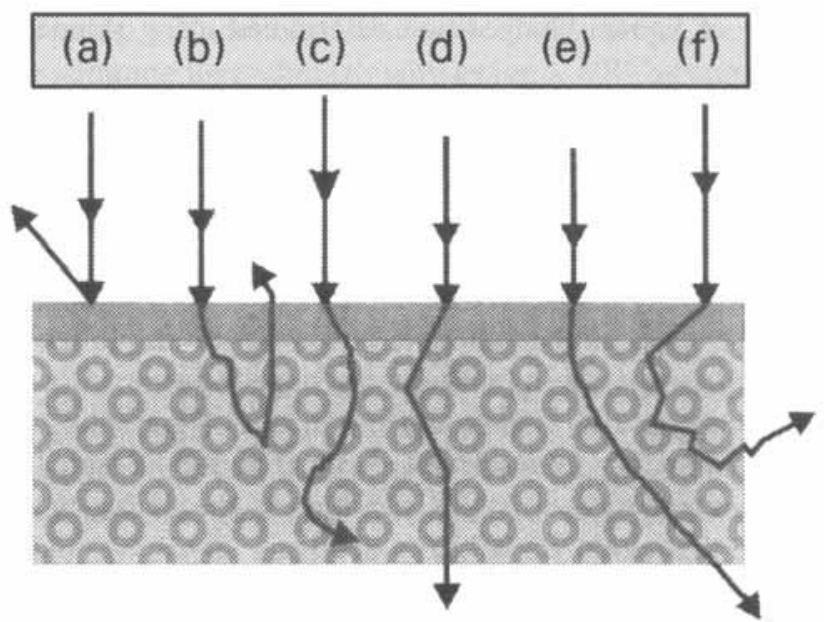

Fig 1. Interaction of near infrared radiation with solid particles in a sample.

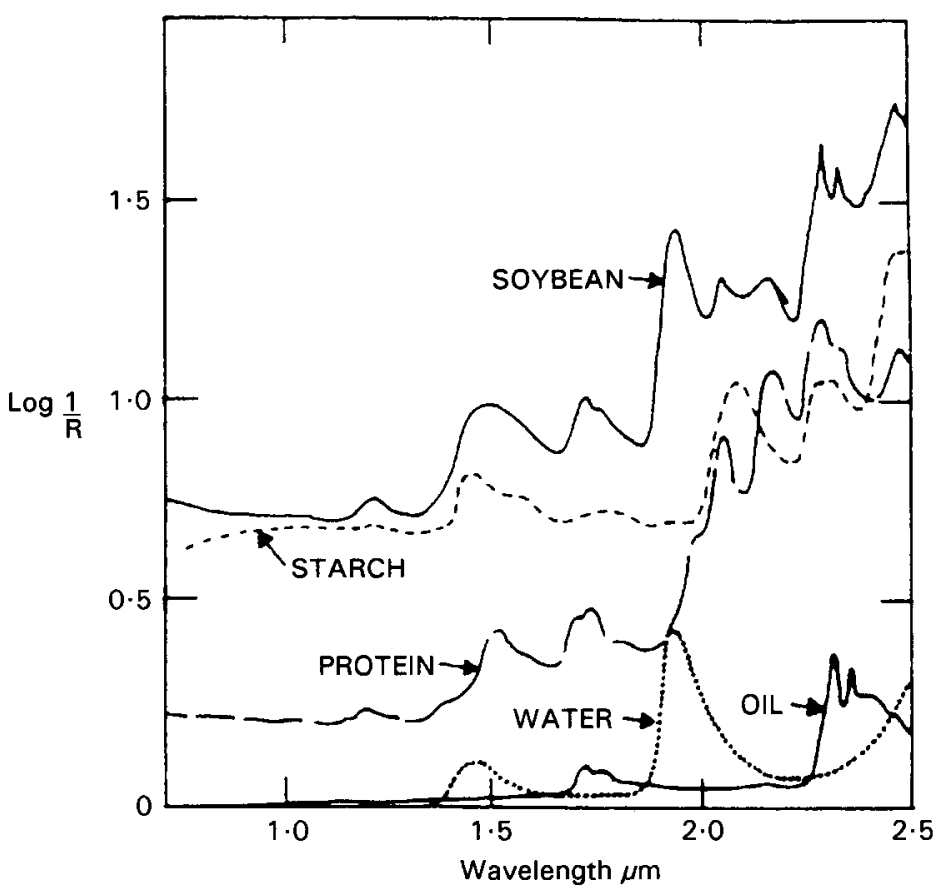

Fig 2. Illustration of the mutually interfering optical spectra from different constituents present in a sample. 
samples of known composition determined using standard chemical methods (primary techniques).

\section{NIR instruments}

There are many instrument models available for NIR analysis and while they differ in several important respects, they all have in some form the following five components, irrespective of whether they operate in transmittance or reflectance: (1) a source of radiant energy, (2) a device for wavelength discrimination, (3) a means of presenting the sample, (4) a detector to convert the radiant energy to an electrical signal and (5) a signal processor and readout (Fig. 3). The most common source of NIR radiation is the quartz halogen tungsten filament lamp that is useful in the region from 320 to $2500 \mathrm{~nm}$.

Components for wavelength discrimination may be classified into two types, filters and monochromators. Discrete filter instruments contain a number of interference filters (usually between six and nineteen) mounted on a rotating flat disc, allowing the radiation from the source to pass sequentially through each filter. Tilting filter instruments take advantage of the dependence of wavelength on the angle of incidence so that a limited tilting of the filter in the light path generates a controlled wavelength shift that in effect scans a narrow band of the spectrum. Monochromators scan the whole wavelength range by using a grating or prism as a dispersing element.

Detection of NIR radiation occurs photoelectrically. The incident photons affect directly the electron state of the photosensitive material of the detectors, so producing an electrical impulse that constitutes the detector output. The most widely used photosensitive material is lead sulphide from 1000 to $2600 \mathrm{~nm}$ and silicon at shorter wavelengths. To minimize losses of transmitted $(T)$ or diffusely reflected $(R)$ radiation the detectors are placed near the sample mounted on a $45^{\circ}$ cone or on an integrating sphere. The signal from the detector is amplified and linearized.

\section{TRANSMITTANCE}

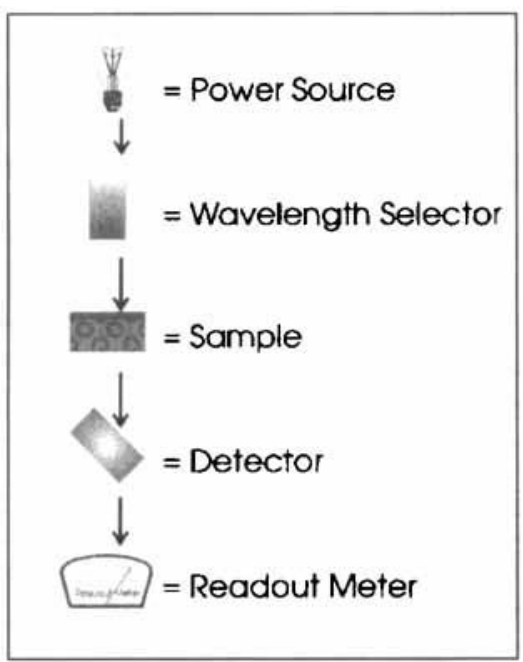

REFLECTANCE

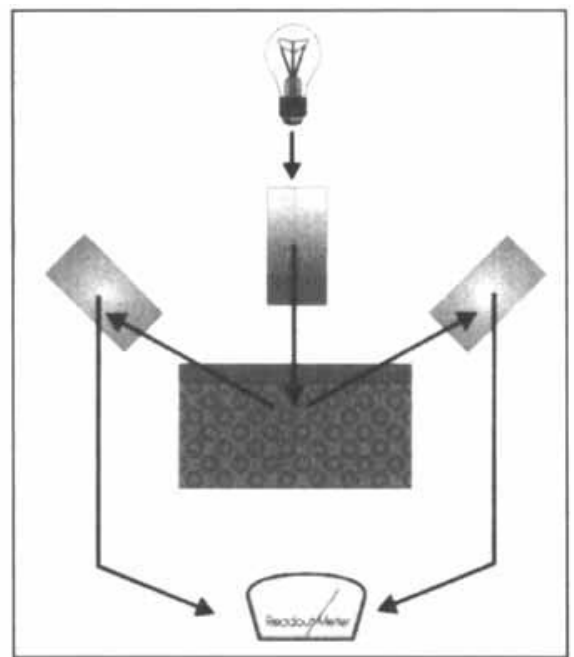

Fig 3. Basic instrument configuration for transmittance and reflectance. 
To produce a nearly linear relationship with concentration over a wide range, instrument responses are mostly converted to the common logarithm (usually as $\log _{10} 1 / \mathrm{R}$ ) by comparison of the sample transmittance or reflectance with that of a standard (mostly ceramics). The resulting data are finally collected as the $\log _{10} 1 / \mathrm{R}$ values, stored and processed using computer hard- and software.

\section{NIR calibration}

The usual procedure for calibrating involves selection of representative samples, acquiring spectra and reference analyses, data pretreatment, statistical modelling and validation. Data pretreatment aims at eliminating nonlinearities due to optical interferences caused by light scatter and remaining specular reflectance. The next step is to derive a mathematical model relating spectral data to reference data, a process called chemometrics. To minimize interferences from the spectra of strongly overlapping constituents and from light scatter variations, measurements on many different wavelengths must be combined. Several multivariate calibration methods are available. They all have as basic form:

$$
Y=\mathrm{a}+\mathrm{b} 1 X 1+\mathrm{b} 2 X 2+\cdots+\mathrm{bk} X \mathrm{k}
$$

where $Y$ is the variable to be measured; the $X 1, X 2, \ldots, X \mathrm{k}$ are $\mathrm{k}$ independent variables, each a combination of one or more spectral values; the b1, b2, ., bk are $k$ regression coefficients and $\mathrm{a}$ is the intercept. In calibration, a set of $X$ and known $Y$ values are used to derive the $\mathrm{b}$ values, whereas in validation and measurement a set of $X$ and the derived $b$ values are used to predict an unknown $Y$.

In multiple linear regression analysis spectral intensities at a few wavelengths are selected, but this technique has difficulties with wavelength choice and collinearity. These problems are avoided by data compression methods, which are more complex in the sense that the $X$ values require lengthier calculations. These methods express a spectrum as the sum of elementary spectra (called loadings or latent variables), each multiplied by a 'score'. The scores (some or all) are then used as $X$ values. The definition of 'elementary' is different according to the method, being sine and cosine functions in the Fourrier transform procedure, spectra of chemical components or representative samples in curve fitting and artificial spectra statistically accounting for either spectral variations in principal components analysis or spectral as well as chemical variations in the partial least squares method.

\section{Application to animal nutrition}

As indicated earlier, feed represents the single largest cost associated with animal production and it is now recognized that accurate and biologically meaningful feed characterization is essential to efficient animal production with minimal environmental impact. NIR spectroscopy is now playing a vital role in this area.

\section{Evaluation of forages}

Forages, either grazed or fed after conservation, supply at least $75 \%$ of the estimated energy and protein requirements of ruminant animals (Beever \& Reynolds, 1994) and in the UK alone grass silage worth some $£ 1.3$ billion is produced each year. The economic and nutritional 
necessity of accurately predicting the energy value of forages prior to their feeding to productive ruminants has been assessed in some detail by Barber et al. (1989).

Most reports attribute the first successful use of NIR spectroscopy for predicting forage digestibility in vitro and in vivo to Norris et al. (1976). Using a scanning monochromator instrument they found $\mathrm{R}^{2}$ values of 0.78 and 0.90 for the prediction of dry matter digestibility in vivo and in vitro respectively. Norris et al. (1976) were also the first to demonstrate, for forages, the enhanced predictive ability of NIR spectra imparted by the use of the second order derivative of the $\log 1 / \mathrm{R}$ spectral data.

In the years following the work of Norris et al. (1976) there was a large number of reports on the use of NIR spectroscopy to predict many aspects of forage composition, many of them devoted to the estimation of chemical fractions such as crude protein and neutral detergent fibre. It is not the intention of this paper to review these areas in detail and for further information on this the reader is referred to the paper of Murray (1993).

Predicting the digestibility in vivo of forages

A large number of developments of NIR spectroscopy to predict digestibility in vivo have been reported by several research groups including work on mixed forages by Lindgren (1983) and on grasses by Robert et al. (1986). In most cases NIR spectroscopy provided a better prediction of digestibility than laboratory procedures.

The most important development in the UK was reported by Barber et al. (1990). They showed for the first time that NIR spectroscopy was able to predict the organic matter digestibility (OMD) of grass silage in vivo more accurately than a range of commonly used laboratory methods. This work used a stepwise multiple linear regression of eight first and second derived spectral terms. A summary of the results obtained during validation of the various relationships is shown in Table 2 .

It is also interesting to note that the work of Barber et al. (1990) highlighted the fact that most traditional relationships which had been developed for predicting digestibility were, strictly speaking, calibrations and had never been exposed to the validation regime necessary for NIR spectroscopy calibrations. More recently, De Boever et al. (1996) have also shown for grass silages made in Belgium that NIR spectroscopy provided the best calibration relationship for OMD in vivo with a variance accounted for value $\left(\mathrm{R}^{2}\right)$ of 0.79 compared with values of $0.68,0.64$ and 0.53 for cellulose digestibility, rumen fluid digestibility and acid detergent lignin determinations respectively.

Successful calibrations have also been developed for the prediction of the digestibility and metabolizable energy (ME) content of other forages including grasses and cereal straws. Givens

Table 2. Comparison of NIR spectroscopy with several laboratory methods for predicting the organic matter digestibility in vivo of grass silage (after Barber et al. 1990)

\begin{tabular}{lcccc}
\hline & \multicolumn{4}{c}{ Validation statistics } \\
\cline { 2 - 5 } Method & $\mathrm{R}^{2}$ & SEP & Slope & Bias \\
\hline NIR-8 term & 0.76 & 2.6 & 0.93 & -0.79 \\
In vitro OMD & 0.64 & 3.6 & 0.89 & -1.85 \\
Pepsin-cellulase & 0.40 & 4.7 & 0.71 & 2.33 \\
Acetyl bromide lignin & 0.14 & 5.3 & 0.48 & 1.18 \\
Modified acid detergent fibre & 0.20 & 5.1 & 0.52 & -0.59 \\
\hline
\end{tabular}

OMD, organic matter digestibility; SEP, standard error of prediction, $\%$. 
et al. (1992a) showed that the ME content of mixed grasses could be predicted by a five term NIR spectroscopy calibration and that this technique was as good as the best traditional laboratory method (pepsin-cellulase). One of the main advantages of the five term NIR spectroscopy equation was that it did not discriminate between spring, summer and autumn grasses or between grasses harvested in different years.

These findings clearly demonstrated the ability of NIR spectroscopy to predict the digestibility in vivo of forages and, for grasses at least, the ME content. Most of the NIR spectroscopy calibrations described above were effected by the multiple linear regression of derived $\log 1 / \mathrm{R}$ spectral data without any inherent knowledge about which parts of the spectrum contained the most information in relation to digestibility.

Important spectral regions for predicting digestibility. Reviews of the literature (Clark \& Lamb, 1991; Deaville \& Baker, 1993) relating to the prediction of forage digestibility by NIR spectroscopy indicate that several wavelength regions regularly appear as being the most important. Table 3 presents a brief summary of some of the reports.

Table 3 shows that the spectral regions around $1650-1670$ and $2260-2280 \mathrm{~nm}$ consistently appear as the most important regions associated with digestibility. Subsequently, by sequentially subtracting spectra associated with the residues of in situ bag incubations in the rumen, Givens et al. (1992b) demonstrated that in cereal straws the 1650 and $2254 \mathrm{~nm}$ regions related to the indigestible fractions of the forage. Deaville et al. (1992) went on to show that these regions related to the most indigestible fractions of the plant cell wall and Deaville \& Givens (1997) have shown that they are also important in relation to rumen degradation of grass silage, maize silage and fresh grass. Other findings (Russell et al. 1989; Deaville \& Givens, 1997) indicate that the regions relate to lignin bonding and this gives further confidence that regions of the NIR spectrum have biological meaning. Further aspects of this have also been discussed by Deaville \& Baker (1993).

Recent findings in relation to the prediction of grass silage digestibility. As a result of the great improvement over traditional procedures, the findings of Barber et al. (1990) were used as a basis of an NIR spectroscopy prediction relationship adapted for routine purposes by all three Government advisory bodies in the UK. However, despite the low standard error of prediction (SEP) value, the introduction of the relationship into large scale use highlighted a number of

Table 3. Primary and secondary near infared spectroscopy wavelength segments used to predict forage digestibility

\begin{tabular}{llccl}
\hline & & \multicolumn{2}{c}{ Wavelength (nm) } & \\
\cline { 3 - 4 } Forage & Predicted term & Primary & Secondary & \\
\hline Mixed & DMD in vivo & 2266 & 1662 & Reference \\
Grass & ME & 1668 & 1364 & Norris et al. (1976) \\
Grass silage & Lignin & 1658 & 2286 & Murray et al. (1987) \\
Hays & DMD in vivo & 1326 & 2266 & Coelho et al. (1988) \\
Hays/grass & ME & 1666 & 1690 & Lindgren (1988) \\
Grass silage & OMD in vivo & 2266 & 1662 & Kridis (1989) \\
Grass & ME & 1658 & 2280 & Givens et al. (1992a) \\
Cereal straw & OMD in vitro & 1662 & ns & Guzmán et al. (1996) \\
\hline \hline
\end{tabular}

DMD, dry matter digestibility; ME, metabolizable energy; ns, not stated; OMD, organic matter digestibility. 


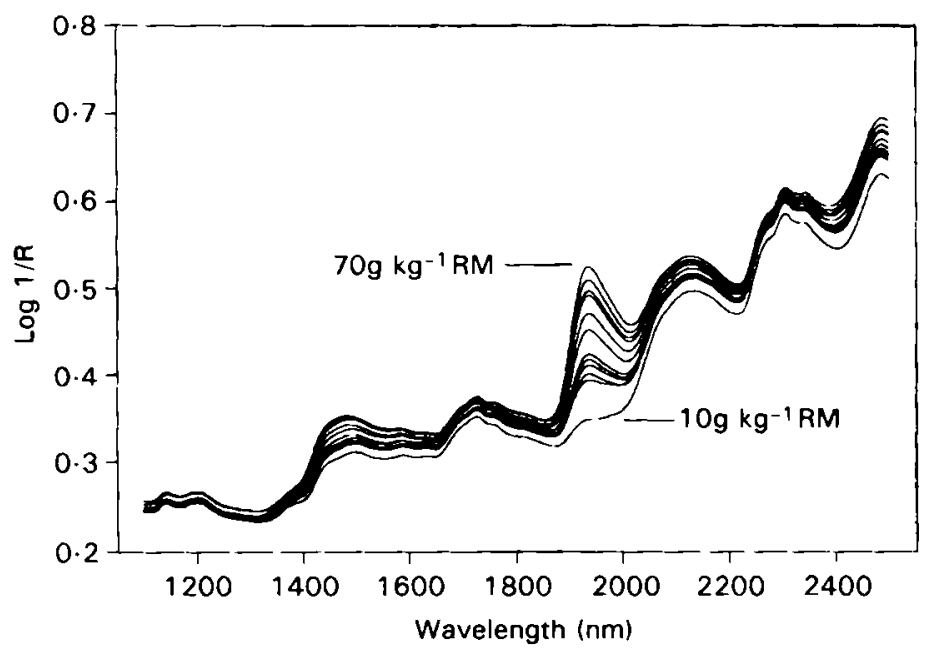

Fig 4. The effect of residual moisture (RM) on the near infrared spectra of grass silage (after Baker et al. 1994).

weaknesses (see Baker \& Barnes, 1990) which related mainly to the sensitivity of the spectral equation, to sample particle size and to variation in residual moisture content of the scanned sample.

As shown in Fig. 4, moisture has a particular influence on the spectra of silage over the $1850-2000 \mathrm{~nm}$ region. Recent research (Baker et al. 1994) has shown that the sensitivity of calibrations to moisture can be substantially reduced by the development of a so-called repeatability file which monitors the spectral changes occurring in silages of different residual moisture contents and then, during calibration, down-weighs the contribution from the moisture sensitive spectral regions.

Variations in particle size can account for up to $90 \%$ of the variance in NIR spectra (Baker \& Barnes, 1990) and can substantially influence the predicted values. Baker et al. (1994) showed that in silage many of the effects of different particle sizes can be overcome by the use of the standard normal variate-detrending (SNV-D) transformation of Barnes et al. (1989). This procedure standardizes the variance of the spectrum to unity with a mean of zero and removes curvilinearity of the spectrum by a second order polynomial.

Multiple linear regression techniques including the modified stepwise regression (MSR) procedure have been extensively used in the past for developing calibrations between spectral data and digestibility in vivo including the relationships reported by Baker \& Barnes (1990) and Barber et al. (1990). However, MSR techniques have the disadvantage that they are able to use only a small amount of the spectral information available. Other statistical procedures such as partial least squares (PLS; Manne, 1987), modified partial least squares (MPLS; Shenk \& Westerhaus, 1991) and principal component analysis (PCA; Cowe \& McNicol, 1985) have been proposed. These methods have the theoretical advantage that they use almost all the spectral data available by first reducing them to a few linear combinations of some hundreds of absorptions. These synthetic variables have the advantage of being independent of each other, unlike the spectral data at different wavelengths.

Shenk \& Westerhaus (1991) showed that MPLS calibrations for predicting the in vitro digestibility of various forages were substantially superior to those based on MSR. Also, Baker 
Table 4. The performance of the best three calibration equations from each statistical technique used for predicting the organic matter digestibility in vivo of grass silage (Baker et al. 1994)

\begin{tabular}{|c|c|c|c|c|c|c|c|}
\hline \multirow{2}{*}{$\begin{array}{l}\text { Equation } \\
\text { number }\end{array}$} & \multirow{2}{*}{$\begin{array}{l}\text { Equation } \\
\text { type }\end{array}$} & \multirow{2}{*}{$\begin{array}{c}\text { Derivatisation } \\
\text { order }\end{array}$} & \multicolumn{2}{|c|}{ Use of } & \multicolumn{2}{|c|}{ Validation } & \multirow[b]{2}{*}{ SM } \\
\hline & & & SC & RF & SEP & $\mathrm{R}^{2}$ & \\
\hline 1 & MPLS & 2 & + & + & 2.35 & 0.82 & 0.84 \\
\hline 2 & MPLS & 2 & + & - & 2.60 & 0.78 & 5.25 \\
\hline 3 & MPLS & 1 & + & + & 2.65 & 0.77 & 2.53 \\
\hline 4 & MSR & 2 & - & - & 2.67 & 0.77 & 3.62 \\
\hline 6 & MSR & 1 & + & - & 2.69 & 0.77 & 4.52 \\
\hline 7 & MSR & 2 & + & + & 2.70 & 0.77 & 4.08 \\
\hline 13 & PCA & 2 & - & + & 3.23 & 0.68 & 1.27 \\
\hline 14 & $P C A$ & 2 & + & - & 3.25 & 0.65 & 2.84 \\
\hline 15 & PCA & 2 & + & + & 3.29 & 0.66 & 2.32 \\
\hline
\end{tabular}

MPLS, Modified partial least squares; MSR, Multiple stepwise regression; PCA, principle components analysis; RF, repeatability file ( + , used; -, not used); SC, scatter correction; SEP, standard error of prediction; SM, sensitivity of moisture. This is a mathematically devised variable that provides a measure of the repeatability of the NIR measurement to the effects of water; the higher the numerical SM value, the greater the error.

et al. (1994) compared the use of MSR, MPLS and PCA for developing calibrations for predicting the OMD in vivo of grass silages. In general, MPLS produced the most accurate predictive relationships followed by MSR; PCA produced equations of rather poor predictive power. Table 4 summarizes the validation statistics for the best three equations from each of the three statistical techniques. Table 4 also shows the effect of using, or not, the SNV-D scatter correction procedure and the use or not of the repeatability file to reduce sensitivity to residual moisture.

The results in Table 4 indicate that the best calibration equation developed was a combination of an MPLS regression of second order derived $\log 1 / \mathrm{R}$ spectral data using both SNVD scatter correction for removing the effect of particle size variation and a repeatability file to reduce water sensitivity. Also of interest is the fact that the best equation did not differentiate between silages made as big bales or in clamps. It is noteworthy that Dardenne et al. (1995) also showed that the use of partial least squares removed much of the confounding effects of moisture, particle size and ambient temperature when predicting the protein content of wheat.

Application of recent findings throughout the UK. Offer (1993) has described a calibration for predicting the OMD in vivo of grass silage which it has been agreed should be the standard for use throughout the UK by both Government advisory services and the feedingstuffs industry. This equation (SEP, $2.40 ; \mathrm{R}^{2}, 0.83$ ) is very closely related to and incorporates all the features of eqn 1 in Table 4. Offer (1993) also described how 'slave' NIR spectrometers can be matched to a 'master' instrument to allow the agreed calibration to become widely used. He emphasized that even after initial matching of instruments by the manufacturer, differences between machines may still persist when complex prediction models are applied. Offer (1993) described how this could be overcome by the use of prediction model specific software.

The capital cost of a scanning NIR spectrometer is high and many commercial laboratories are equipped with less expensive fixed filter instruments which make measurements at only 19 spectral points (compared with several hundreds for scanning monochromators). Accordingly, Offer (1993) has described an investigation to examine the possibility of developing a sec- 
Table 5. Prediction errors for organic matter digestibility in vivo and metabolizable energy of grass silage using different approaches (after Offer, 1993)

\begin{tabular}{lcccc}
\hline & & \multicolumn{2}{c}{$\%$ of cases failing to meet ME tolerance } \\
\cline { 3 - 5 } Initial predicted term & NIR instrument & SEP & $\pm 0.5 \mathrm{MJ} / \mathrm{kg} \mathrm{DM}$ & $\pm 1.0 \mathrm{MJ} / \mathrm{kg} \mathrm{DM}$ \\
\hline MADF & 19 filter & 5.30 & 53 & 21 \\
OMD in vivo & 19 filter & 3.00 & 26 & 3 \\
OMD in vivo & Scanning & 2.53 & 19 & $<1$ \\
\hline
\end{tabular}

DM, dry matter; MADF, modified acid detergent fibre; ME, metabolizable energy (for calculation see Offer, 1993); OMD, organic matter digestibility; SEP, standard error of prediction.

ondary calibration on 19 filter instruments using predicted data from the scanning machine. The results showed that while there was a loss of accuracy associated with the use of the 19 filter instrument, the approach was still a substantial improvement over methods involving modified acid detergent fibre. A summary of the errors as presented by Offer (1993) is shown in Table 5.

\section{Prediction of voluntary intake of forages}

In many animal production systems energy intake from forage is more influenced by voluntary dry matter (DM) intake than by the energy concentration of the forage DM. Accordingly, there have been many attempts to predict intake from various attributes of the forage composition (see Minson, 1982 for review) although it should be noted that there are often many nonforage factors which may influence intake. These would include the amount of supplementary feed given, as well as animal and environmental factors.

It has been proposed (AFRC, 1991) that NIR spectroscopy could be one of the most promising areas for predicting the voluntary intake of grass silage since the spectra contain information on the entire chemistry of the feed. In fact NIR spectroscopy has been successfully used to predict the intake of mainly nonfermented forages. The early work of Norris et al. (1976) and the more recent studies of Ward et al. (1982) and Flinn et al. (1992) are summarized in Table 6.

The work of Flinn et al. (1992) was unusual in that it involved the use of an MPLS regression where the NIR spectral data of faeces were related to forage intake, intake having been originally calculated from the n-alkane dosing procedure of Mayes et al. (1986).

Recently it has also been shown (Steen et al. 1995) that NIR spectroscopy can accurately predict the voluntary intake of grass silage by cattle. They measured the intakes of 136 grass

Table 6. Prediction of voluntary dry matter intake of forages by NIR spectroscopy

\begin{tabular}{|c|c|c|c|c|c|c|}
\hline \multirow[b]{2}{*}{ Forage } & \multirow{2}{*}{$\begin{array}{c}\text { Number of } \\
\text { measurements }\end{array}$} & \multicolumn{2}{|c|}{$\begin{array}{c}\text { Intake } \\
\left(g / k g L W^{075} / d\right)\end{array}$} & \multicolumn{2}{|c|}{$\begin{array}{c}\text { NIR } \\
\text { prediction }\end{array}$} & \multirow[b]{2}{*}{ Reference } \\
\hline & & Species & Range & $\mathrm{R}^{2}$ & SEP & \\
\hline $\begin{array}{l}\text { Mixed } \\
\text { Grazed pasture } \\
\text { Grazed pasture }\end{array}$ & $\begin{array}{l}76 \\
21 \\
80\end{array}$ & $\begin{array}{l}\text { Sheep } \\
\text { Cattle } \\
\text { Sheep }\end{array}$ & $\begin{array}{l}39.7-114.3 \\
52 \cdot 6-112.3 \\
430-1458 \dagger\end{array}$ & $\begin{array}{l}0.62 \\
0.72 \\
0.80\end{array}$ & $\begin{array}{r}7.8 \\
9.6 \\
140\end{array}$ & $\begin{array}{l}\text { Norris et al. (1976) } \\
\text { Ward et al. (1982) } \\
\text { Flinn et al. (1992) }\end{array}$ \\
\hline
\end{tabular}

$\dagger$, organic matter intake/animal per day.

LW, live weight; SEP, standard error of prediction. 
silages by 192 individually fed beef cattle and compared NIR spectroscopy with some thirty other laboratory measurements on the silage, digestibility in vivo and rumen in situ DM degradability for their ability to predict voluntary intake. The best overall relationship was between NIR spectra and intake with $R^{2}$ values of 0.86 and 0.71 for calibration and blind validation respectively and an SEP value of $5.5 \mathrm{~g} / \mathrm{kg}$ live weight $\left(\mathrm{LW}^{0.75}\right)$. Of the other measurements the next best relationships with intake were obtained with electrometric titration $\left(\mathrm{R}^{2}\right.$ $0.53)$, digestibility in vivo $\left(R^{2} 0.30\right)$ and DM degradability $\left(R^{2} 0.28\right)$.

The fact that NIR spectroscopy seems to offer considerable opportunities for predicting intake suggests that such studies should be considerably extended. The time and funding required to build up further suitable databases to relate spectral data directly to intake will be considerable but is worth pursuing since in addition to predicting intake the spectra may uncover some of the factors in forages which functionally influence intake.

\section{Prediction of new aspects of forage energy value}

Many systems for evaluating the energy value of forages are based on measurements of digestibility or ME content. It is now becoming clear that this unifying concept of energy is inadequate (AFRC, 1992) and that it is important to distinguish between the energy in the forages which is available for rumen microbial growth (fermentable energy) and that which is directly available to the host animal.

Of particular importance for ensiled forages is the fact that they may contain substantial amounts of lactic acid and volatile fatty acids, which provide little or no fermentable energy (AFRC, 1992). Thus, an important future role of NIR spectroscopy would be to predict the concentrations of the individual acids or total fermentation acids and there is now evidence in the literature that this may be achieved. Abrams et al. (1988) have shown that it is possible to derive reasonably successful calibrations for lactic, acetic and butyric acids following the scanning of fresh undried silages, although these calibrations were not validated. An interesting approach to the problem has been reported by Snyman \& Joubert (1992) who showed that fermentation acids in sorghum silages could be adequately predicted by NIR spectroscopy if the fermentation acids were first converted to their corresponding salts before microwave drying. Recently Deaville \& Givens (1996a) showed that an MPLS model of the NIR spectra obtained from 800 fresh undried silages could be used to predict lactic acid and volatile fatty acids. A summary of the NIR spectroscopy statistics from this study is shown in Table 7.

While for silages the determination of fermentation acids represents an approach to estimating fermentable energy content by difference, an alternative would be a direct prediction of

Table 7. Estimate of fermentation acids in silages by NIR spectroscopy (Deaville \& Givens, 1996a)

\begin{tabular}{|c|c|c|c|c|}
\hline \multirow[b]{2}{*}{ Fermentation acid } & \multicolumn{2}{|c|}{ Calibration } & \multicolumn{2}{|c|}{ Validation } \\
\hline & $\mathrm{R}^{2}$ & SEC & $\mathrm{R}^{2}$ & SECV \\
\hline $\begin{array}{l}\text { Lactic acid } \\
\text { Acetic acid } \\
\text { Propionic acid } \\
\text { n-Butyric acid }\end{array}$ & $\begin{array}{l}0.73 \\
0.69 \\
0.59 \\
0.87\end{array}$ & $\begin{array}{l}4.24 \\
1.72 \\
0.47 \\
0.82\end{array}$ & $\begin{array}{l}0.72 \\
0.66 \\
0.56 \\
0.86\end{array}$ & $\begin{array}{l}4.37 \\
1.80 \\
0.49 \\
0.87\end{array}$ \\
\hline
\end{tabular}

SEC, standard error of calibration ( $g / \mathrm{kg}$ fresh weight); SECV, standard error of cross validation ( $g / \mathrm{kg}$ fresh weight) 
fermentability. The gas production technique originally described by Menke et al. (1979) and modified by, for example, Cone et al. (1996) is a method which has the potential to measure fermentability more directly, including the fermentation rate. Recently, an attempt to integrate gas production studies on forages with NIR spectroscopy was reported (Herrero et al. 1996). These workers showed that it was possible to derive reasonable NIR predictive relationships for cumulative gas volumes produced between 6 and $48 \mathrm{~h}$ of incubation although rates of gas production could not be predicted. Interestingly, the wavelength segments associated with gas production indicated that the primary wavelength was always located between 1664 and $1696 \mathrm{~nm}$, which is in the same region as wavelengths associated with digestibility (p. 91). This would seem to be a very fruitful area requiring further research.

With the possible exception of starch in maize silage, the cell wall fraction represents the major fermentable energy yielding substrate in forages. However, the fermentability of cell walls varies greatly, more or less in line with overall digestibility. There appear to be few reported estimates of the extent and rate of fermentation of forages produced in the UK, although some in vitro estimates of cell wall digestion dynamics of grass silages have been presented by Foulkes (1993) and Deaville \& Givens (1996b). The latter authors also examined the use of NIR spectroscopy for predicting cell wall degradation parameters of 113 grass silages and some results are shown in Table 8.

The data in Table 8 indicate that NIR spectroscopy has considerable scope for predicting the potential and effective cell wall degradability, although it is clear that prediction of the rate of degradation and the lag phase require further work and indeed may prove not to be possible by absorption spectroscopy. In this regard it may be questioned whether these data reflect the inability of NIR spectroscopy or the biological validity of the values determined. Also, as proposed by Herrero et al. (1996), the failure of NIR spectroscopy to predict dynamic values may relate to the exponential nature of the model used altering the distribution and range of the parameters thus preventing a good fit by the calibration methods used which are all multivariate and linear.

\section{Prediction of aspects of protein value}

The literature now contains many reports where NIR spectroscopy has been used to predict the crude protein content of forages and other feeds. However, for ruminant animals it is now recognized (AFRC, 1992) that protein quality is more accurately described by estimating three aspects of protein digestion in the rumen. These are the immediately soluble fraction, the insoluble but degradable fraction and the rate of degradation of the degradable fraction. These measurements are normally carried out using the nylon bag method, which not only requires the use of cannulated animals, but is also slow and expensive.

Table 8. Prediction of in vitro cell wall degradability characteristics of grass silage by NIR spectroscopy (Deaville \& Givens, 1996b)

\begin{tabular}{|c|c|c|c|c|c|}
\hline \multirow[b]{2}{*}{ Degradability parameter } & \multirow[b]{2}{*}{ Mean } & \multicolumn{2}{|c|}{ Calibration } & \multicolumn{2}{|c|}{ Cross validation } \\
\hline & & $\mathrm{R}^{2}$ & SEC & $\mathrm{R}^{2}$ & SECV \\
\hline $\begin{array}{l}\text { Potential degradability (\%) } \\
\text { Effective degradability (\%) } \\
\text { Rate of degradation (/h) } \\
\text { Lag phase (h) }\end{array}$ & $\begin{array}{l}73.3 \\
53.8 \\
0.07 \\
2.49\end{array}$ & $\begin{array}{l}0.73 \\
0.83 \\
0.50 \\
0.32\end{array}$ & $\begin{array}{l}3.76 \\
2.42 \\
0.01 \\
0.81\end{array}$ & $\begin{array}{l}0.66 \\
0.70 \\
0.36 \\
0.17\end{array}$ & $\begin{array}{l}4.27 \\
3.21 \\
0.01 \\
0.89\end{array}$ \\
\hline
\end{tabular}

SEC, standard error of calibration; SECV, standard error of cross validation. 
For 19 frozen fresh grasses, Waters \& Givens (1992), demonstrated that it was possible to derive NIR spectroscopy calibrations for the nitrogen degradation values although overall the calibrations were relatively weak and the shortage of samples prevented any validation. Better results were obtained when the population was split into primary growths and regrowths although the population sizes were very small. Further studies on the use of NIR spectroscopy for predicting the nitrogen degradability characteristics of forages are urgently needed.

Since in grass silage a very high but varying proportion $(0.45-0.75)$ of the nitrogen present is soluble in water and hence in rumen fluid (ADAS, 1989), the ability to predict the solubility by NIR spectroscopy would be a major improvement over simply predicting total nitrogen or crude protein concentration. Abrams et al. (1988) showed that with various silages, the solubility and insolubility of nitrogen in buffered sodium chloride solution could be estimated by a six term MSR calibration of second order derived $\log 1 / \mathrm{R}$ spectral data. The scanning was performed on fresh undried silages and no independent validation was carried out. Some of the results from Abrams et al. (1988) are shown in Table 9.

The silages of Abrams et al. (1988) tended to be of higher DM content (394 $\pm 137 \mathrm{~g} / \mathrm{kg})$ than those commonly observed in the UK. In recent work (E. R. Deaville \& D. I. Givens, unpublished) the use of NIR spectroscopy with fresh undried silage to predict the soluble nitrogen and ammonia nitrogen concentrations was examined. Initial calibration results (Figs 5 and 6) suggest that an MPLS calibration has a high prediction ability for these fractions, although further work including independent validation is required.

\section{Evaluation of nonforages}

Modern livestock feeding strongly relies on nonforage feeds or concentrates. For poultry and most fattening pigs they form the complete diet, but also for cattle, particularly for highproducing dairy cows and fast growing bulls, they often make up more than $50 \%$ of the total diet dry matter. Concentrate feedstuffs mainly comprise cereals, pulses, oilseeds and byproducts of agro-industrial and animal origin. To a small extent some of them are used directly on farm, but the most important use is as raw materials for manufacturing compound feeds. To formulate compound feeds corresponding to predefined nutrient and quality specifications at least cost, the raw materials available are selected by linear programming on the assumption that the data for individual raw materials are additive. Owing to ever increasing quality demands, the feeding value of the available raw materials should be known as accurately as possible. Moreover, the nutritional information necessary to meet animal requirements

Table 9. Estimation of nitrogenous constituents in silage by NIR spectroscopy (after Abrams et al. 1988)

\begin{tabular}{lcccc}
\hline \hline & $\begin{array}{c}\text { Mean value } \\
\text { Nitrogen fraction }\end{array}$ & $\mathrm{SD}$ & \multicolumn{2}{c}{ Calibration statistics } \\
\cline { 3 - 5 } & $(\mathrm{kg}$ fresh weight) & $\mathrm{R}^{2}$ & $\mathrm{SEC}$ \\
\hline Total nitrogen & 9.55 & 4.49 & 0.98 & 0.70 \\
Soluble nitrogen & 3.48 & 1.99 & 0.92 & 0.58 \\
Insoluble nitrogen & 5.97 & 2.70 & 0.98 & 0.35 \\
\hline \hline
\end{tabular}

SD, standard deviation; SEC, standard error of calibration. 


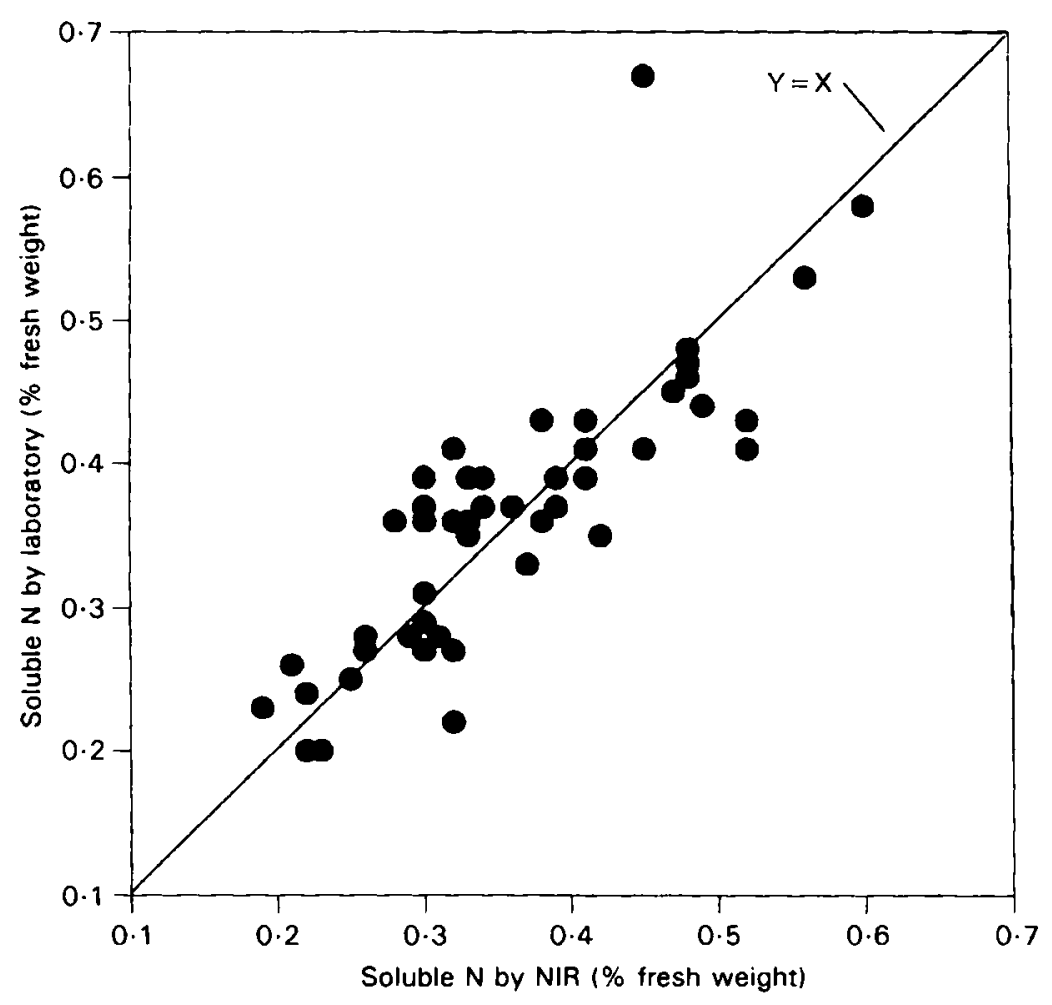

Fig 5. Prediction of soluble nitrogen in grass silage by NIR spectroscopy.

continually changes and increases due to new scientific insights, higher demands from consumers and legislation and increasing concern about the environment.

The classic proximate composition according to the Weende scheme, measuring the crude nutrients protein, fibre, fat and ash and calculating the other carbohydrates by difference, is increasingly replaced by smaller, better defined and/or more homogeneous chemical entities. The production potential of feedstuffs is expressed in terms of energy and protein value, differing according to animal species and production type. Present energy systems in most European Union countries are based on ME or net energy for ruminants and digestible energy, ME or net energy for pigs and poultry. The energy value of a feed is assessed from calorimetric determinations of the various losses in the animal or more generally calculated from regression equations based on digestible nutrients. Protein systems have recently been refined which should result in more efficient animal production but also in reduction of nitrogen losses to the environment. Protein available for absorption in ruminants is based on a distinction between soluble, rumen degradable and undegradable fractions using in situ incubations of feeds in the rumen and intestines of cannulated animals. For pig and poultry feeds the availability of protein and essential amino acids is examined in pigs cannulated at the ileal level and using caecectomized birds. Besides energy and protein, the contents of major and trace elements need to be known. Owing to reduction of soil and water pollution, particularly pollution by phosphorus, the content of $\mathrm{P}$ and its bio-availability in vegetable feedstuffs have recently received much interest. In view of the demand for more lean meat increased attention must also be paid to the fatty acid composition of nonruminant feeds and the ratio of saturated to unsaturated fatty 


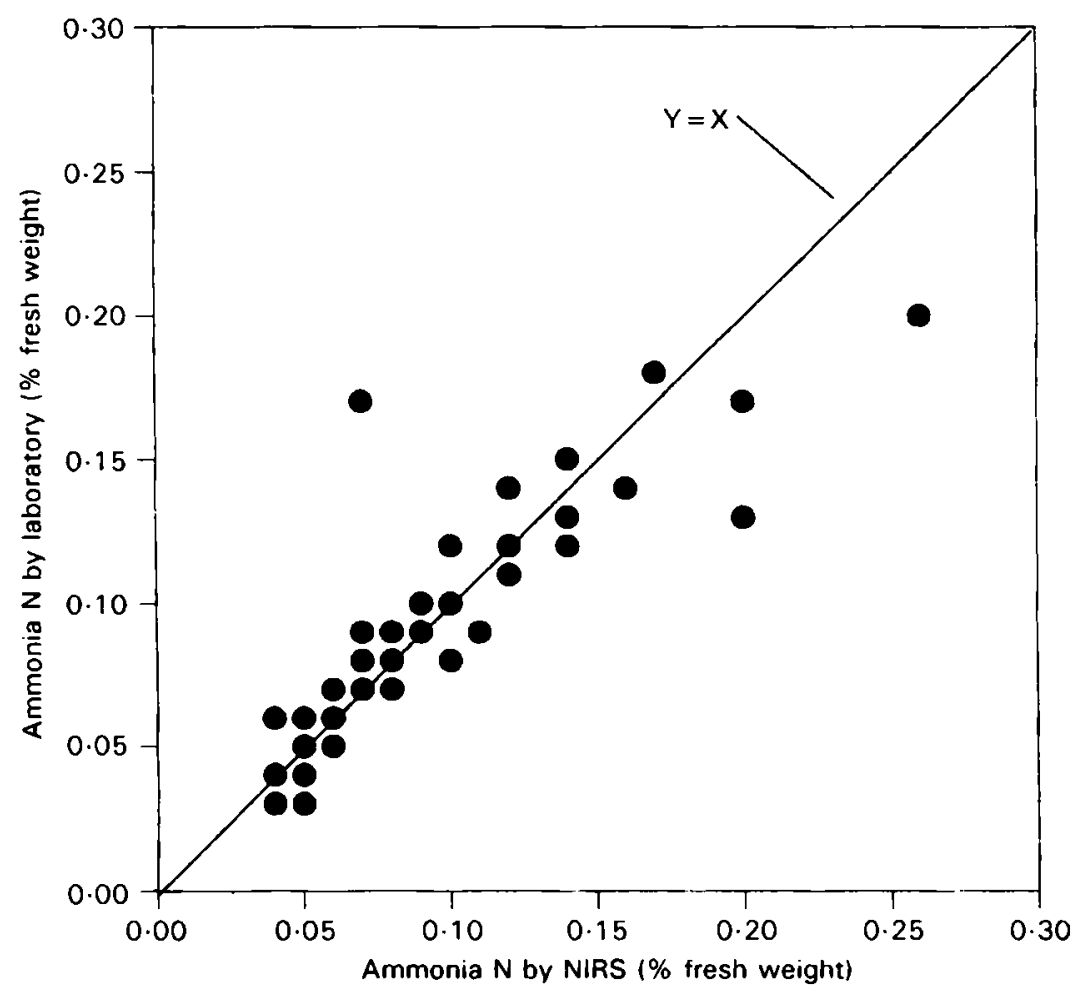

Fig 6. Prediction of ammonia nitrogen in grass silage by NIR spectroscopy.

acids. In many raw materials the presence of antinutritive factors and/or mycotoxins is important. From the foregoing it is clear that feed manufacturers are not able to carry out all required laboratory analyses, not to mention in vivo experiments.

In practice, the evaluation of raw ingredients is generally restricted to a classic proximate analysis. Some companies with well equipped laboratories are able to carry out further analyses including, for example, in vitro digestibility by means of commercial enzyme preparations. Most information, however, is obtained from feed tables. Although mean tabular values for feedstuffs like cereals, pulses and oilseeds are a good approach, they often fail for highly varying by-products of agro-industrial and animal origin. Table 10 gives an idea of the variation in chemical composition of some common raw materials.

Further, the compound feed manufacturer has few tools to monitor and control the mixture during and after the compounding process. On the other hand, because of the laborious and time consuming methods, the quality control analysis by official bodies is very limited in number and parameters. The label for commercial compound feeds is only obliged to mention the proximate composition but also lysine for pigs and methionine for poultry, whereas the energy value is optional. This can lead to dubious practices in feed trading and unfair competition. Moreover, the farmer is only partly and sometimes wrongly informed about the nutritive value of purchased feeds.

The recent introduction of the NIR spectroscopy technique has opened new perspectives for the rapid evaluation of feeds. In the following, the application of NIR spectroscopy to the analysis of raw materials and compound feeds will be reviewed, taking into account that the 
Table 10. Chemical composition (\%) and standard error of calibration (SEC, \%) obtained for concentrate feeds with a NIR filter instrument (after Gerlach, 1990)

\begin{tabular}{|c|c|c|c|c|c|c|c|}
\hline Feedstuff & & Moisture & Protein & Fat & Fibre & Ash & Starch \\
\hline Wheat & $\begin{array}{l}\text { Range } \\
\text { SEC }\end{array}$ & $\begin{array}{l}11-19 \\
0.2\end{array}$ & $\begin{array}{l}10-15 \\
0.4\end{array}$ & - & - & - & $\begin{array}{l}54-60 \\
0.8\end{array}$ \\
\hline Barley & $\begin{array}{l}\text { Range } \\
\text { SEC }\end{array}$ & $\begin{array}{l}10-15 \\
0.2\end{array}$ & $\begin{array}{l}9-13 \\
0.3\end{array}$ & - & - & - & $\begin{array}{l}49-55 \\
0.9\end{array}$ \\
\hline Maize & $\begin{array}{l}\text { Range } \\
\text { SEC }\end{array}$ & $\begin{array}{l}12-15 \\
0.2\end{array}$ & $\begin{array}{l}8-11 \\
0.3\end{array}$ & $\begin{array}{l}3-5 \\
0.3\end{array}$ & - & - & $\begin{array}{l}63-67 \\
0.7\end{array}$ \\
\hline Wheat feed meal & $\begin{array}{l}\text { Range } \\
\text { SEC }\end{array}$ & $\begin{array}{l}11-14 \\
0.1\end{array}$ & $\begin{array}{l}13-19 \\
0.3\end{array}$ & - & $\begin{array}{l}1-5 \\
0.3\end{array}$ & $\begin{array}{l}2-4 \\
0.2\end{array}$ & $\begin{array}{l}35-59 \\
0.9\end{array}$ \\
\hline Wheat middlings & $\begin{array}{l}\text { Range } \\
\text { SEC }\end{array}$ & $\begin{array}{l}9-13 \\
0.2\end{array}$ & $\begin{array}{l}14-19 \\
0.2\end{array}$ & $\begin{array}{l}3-5 \\
0.2\end{array}$ & $\begin{array}{l}4-10 \\
0.4\end{array}$ & $\begin{array}{l}3-5 \\
0.2\end{array}$ & $\begin{array}{l}14-35 \\
0.6\end{array}$ \\
\hline Wheat bran & $\begin{array}{l}\text { Range } \\
\text { SEC }\end{array}$ & $\begin{array}{l}1-14 \\
0.3\end{array}$ & $\begin{array}{l}14-18 \\
0.3\end{array}$ & - & $\begin{array}{l}8-11 \\
0.5\end{array}$ & - & $\begin{array}{l}10-24 \\
1.0\end{array}$ \\
\hline Maize feed meal & $\begin{array}{l}\text { Range } \\
\text { SEC }\end{array}$ & $\begin{array}{l}11-17 \\
0.2\end{array}$ & $\begin{array}{l}6-11 \\
0.7\end{array}$ & $\begin{array}{l}1-5 \\
0.2\end{array}$ & $\begin{array}{l}3-9 \\
0.4\end{array}$ & $\begin{array}{l}1-3 \\
0.3\end{array}$ & - \\
\hline Maize germ meal & $\begin{array}{l}\text { Range } \\
\text { SEC }\end{array}$ & $\begin{array}{l}10-16 \\
0.2\end{array}$ & $\begin{array}{l}10-16 \\
0.5\end{array}$ & $\begin{array}{l}1-5 \\
0.2\end{array}$ & $\begin{array}{l}5-9 \\
0.5\end{array}$ & $\begin{array}{l}3-7 \\
0.5\end{array}$ & $\begin{array}{l}31-40 \\
1.0\end{array}$ \\
\hline Maize gluten feed & $\begin{array}{l}\text { Range } \\
\text { SEC }\end{array}$ & $\begin{array}{l}9-13 \\
0.3\end{array}$ & $\begin{array}{l}18-23 \\
0.4\end{array}$ & $\begin{array}{l}2-5 \\
0.3\end{array}$ & $\begin{array}{l}6-11 \\
0.5\end{array}$ & - & - \\
\hline Tapioca & $\begin{array}{l}\text { Range } \\
\text { SEC }\end{array}$ & $\begin{array}{l}10-14 \\
0.2\end{array}$ & - & - & - & - & $\begin{array}{l}63-76 \\
1.2\end{array}$ \\
\hline Soyabean meal & $\begin{array}{l}\text { Range } \\
\text { SEC }\end{array}$ & $\begin{array}{l}9-16 \\
0.2\end{array}$ & $\begin{array}{l}41-48 \\
0.7\end{array}$ & $\begin{array}{l}1-3 \\
0.2\end{array}$ & $\begin{array}{l}3-10 \\
0.6\end{array}$ & - & - \\
\hline Coconut meal & $\begin{array}{l}\text { Range } \\
\text { SEC }\end{array}$ & $\begin{array}{l}5-11 \\
0.2\end{array}$ & $\begin{array}{l}18-24 \\
0.4\end{array}$ & $\begin{array}{l}2-15 \\
0.3\end{array}$ & - & - & - \\
\hline Palm kernel meal & $\begin{array}{l}\text { Range } \\
\text { SEC }\end{array}$ & $\begin{array}{l}6-15 \\
0.3\end{array}$ & $\begin{array}{l}12-18 \\
0.4\end{array}$ & $\begin{array}{l}1-11 \\
0.3\end{array}$ & - & - & - \\
\hline Sunflower seed meal & $\begin{array}{l}\text { Range } \\
\text { SEC }\end{array}$ & $\begin{array}{l}7-16 \\
0.3\end{array}$ & $\begin{array}{l}25-35 \\
1.0\end{array}$ & $\begin{array}{l}1-4 \\
0.3\end{array}$ & $\begin{array}{l}18-28 \\
1.3\end{array}$ & - & - \\
\hline Rape seed meal & $\begin{array}{l}\text { Range } \\
\text { SEC }\end{array}$ & $\begin{array}{l}8-15 \\
0.3\end{array}$ & $\begin{array}{l}33-40 \\
0.4\end{array}$ & $\begin{array}{l}1-6 \\
0.2\end{array}$ & - & - & - \\
\hline Soyabeans & $\begin{array}{l}\text { Range } \\
\text { SEC }\end{array}$ & $\begin{array}{l}6-13 \\
0.2\end{array}$ & $\begin{array}{l}36-39 \\
0.3\end{array}$ & $\begin{array}{l}17-21 \\
0.3\end{array}$ & $\begin{array}{l}5-9 \\
0.7\end{array}$ & - & - \\
\hline Field beans & $\begin{array}{l}\text { Range } \\
\text { SEC }\end{array}$ & $\begin{array}{l}9-15 \\
0.2\end{array}$ & $\begin{array}{l}23-30 \\
0.4\end{array}$ & $\begin{array}{l}1-2 \\
0.2\end{array}$ & $\begin{array}{l}6-10 \\
0.5\end{array}$ & $\begin{array}{l}2-5 \\
0.3\end{array}$ & $\begin{array}{l}33-40 \\
0.7\end{array}$ \\
\hline Peas & $\begin{array}{l}\text { Range } \\
\text { SEC }\end{array}$ & $\begin{array}{l}9-16 \\
0.2\end{array}$ & $\begin{array}{l}20-24 \\
0.3\end{array}$ & $\begin{array}{l}1-2 \\
0.1\end{array}$ & $\begin{array}{l}4-9 \\
0.4\end{array}$ & - & $\begin{array}{l}39-48 \\
0.8\end{array}$ \\
\hline Sugar beet pulp & $\begin{array}{l}\text { Range } \\
\text { SEC }\end{array}$ & $\begin{array}{l}5-12 \\
0.3\end{array}$ & - & - & $\begin{array}{l}5-17 \\
0.6\end{array}$ & $\begin{array}{l}5-9 \\
0.7\end{array}$ & - \\
\hline Citrus pulp & $\begin{array}{l}\text { Range } \\
\text { SEC }\end{array}$ & $\begin{array}{l}8-13 \\
0.2\end{array}$ & $\begin{array}{l}6-9 \\
0.3\end{array}$ & $\begin{array}{l}2-5 \\
0.2\end{array}$ & $\begin{array}{l}12-14 \\
0.3\end{array}$ & - & - \\
\hline Fishmeal & $\begin{array}{l}\text { Range } \\
\text { SEC }\end{array}$ & $\begin{array}{l}6-13 \\
0.2\end{array}$ & $\begin{array}{l}57-75 \\
1.0\end{array}$ & $\begin{array}{l}6-13 \\
0.6\end{array}$ & - & - & - \\
\hline Meat and bone meal & $\begin{array}{l}\text { Range } \\
\text { SEC }\end{array}$ & $\begin{array}{l}2-10 \\
0.4\end{array}$ & $\begin{array}{l}47-63 \\
1.2\end{array}$ & $\begin{array}{l}8-21 \\
0.6\end{array}$ & - & - & - \\
\hline
\end{tabular}

literature is less extensive than for forages, which have received greater attention from research institutes. From pp. $85-88$ it is clear that NIR spectroscopy is applicable only to chemical or chemically related characteristics. Moreover, one should make a distinction between the characteristics inherent in the feed and those that result from interaction between feed and animal (for example, digestibility, energy value). The possibilities for NIR spectroscopy then 
depend on their relationship with chemical entities and also on animal variation. Following its success in the grain industry for predicting moisture and protein in cereals and oil in seeds, NIR spectroscopy was quickly adopted by the feed industry. In the early 1980s, the major feed companies started to use NIR spectroscopy and develop their own calibrations using analytical data derived in their own laboratories. Later, research institutes and private organizations began to develop calibrations in order to make NIR spectroscopy available for small and medium sized companies as well.

\section{Raw materials}

Chemical composition. Besides more frequent quality control in the feed mill, the rapidity of NIR spectroscopy offers the advantage that batches of raw materials may be analysed at an early stage, i.e. in the country of origin or during transshipment. When specifications agreed in the purchase contract are not met, batches can be refused immediately or after confirmation from the laboratory.

In Germany, the 'Forschungsinstitut Futtermitteltechnik' at Braunschweig developed calibrations for 22 common raw materials (Gerlach, 1990)-see Table 10. For each raw material 80 to 100 samples were collected. Using a Technicon InfraAlyzer 400 and a Percon Inframatic 8120 with respectively 19 and 20 filters, two common instruments in the industry, up to six nutrients, depending on the characteristics of the feed, were calibrated, i.e. moisture, crude protein, crude fat, crude fibre, starch and ash.

The standard error of calibration (SEC) for moisture amounted to $2-4 \mathrm{~g} / \mathrm{kg}$ for all materials; for protein SEC varied from $2 \mathrm{~g} / \mathrm{kg}$ for maize to $12 \mathrm{~g} / \mathrm{kg}$ for animal meal; for oil, SEC amounted to $2-3 \mathrm{~g} / \mathrm{kg}$ for most products, except for animal and fish meal $(6 \mathrm{~g} / \mathrm{kg})$; crude fibre always showed an SEC between 3 and $6 \mathrm{~g} / \mathrm{kg}$, except for sunflower seed meal $(13 \mathrm{~g} / \mathrm{kg}$ ); for starch, SEC varied between $6 \mathrm{~g} / \mathrm{kg}$ for wheat middlings and $12 \mathrm{~g} / \mathrm{kg}$ for tapioca; for ash, SEC varied between 2 and $8 \mathrm{~g} / \mathrm{kg}$. For sugar beet pulp, sugar content could be calibrated with an error of $7 \mathrm{~g} / \mathrm{kg}$. This research also revealed that calibrations for wheat and maize combined with their respective by-products were less accurate than those for the separate products.

In Denmark, the Biotechnological Institute at Kolding developed calibrations to predict proximate composition of nine common raw materials by means of a Technicon IA 400 (Vejgaard et al. 1987). Two private firms, Pre-Mervo in Utrecht, The Netherlands (De Vries \& De Jong, 1991) and Nutrilab in Giessen, Germany, sell calibrations for proximate composition of raw materials developed on Technicon 19-filter instruments. Generally, the accuracy of the published NIR spectroscopy equations is very comparable with minor differences due to the choice of the samples and the precision of the reference methods. Calibrations are transferred by predicting about 10 calibration samples and adjusting bias (seldom slope). Depending on the contract conditions they are more or less frequently maintained and eventually updated. Recently a network for raw material control in the feed industry was established in Spain (Moya et al. 1995) in which calibrations were developed on an NIRSystems ${ }^{\mathrm{TM}} 5000$ scanning instrument $(1100-2500 \mathrm{~nm})$ placed in a central laboratory at Madrid. Rugged NIRSystems ${ }^{\text {TM }}$ 4500 instruments covering the $1300-2400 \mathrm{~nm}$ range, located in the feed companies, are used as satellites after standardizing the spectra to the master instrument. Instruments with more wavelength capabilities appear to offer little gain in accuracy for predicting the chemical composition of raw materials.

Energy value. The energy value gives a global view of the nutrient content of a feed and has also the greatest impact on its price. For raw materials, however, the in vivo data are generally too limited for product specific and robust calibrations. To the authors' knowledge, no NIR 
spectroscopy work is reported for predicting in vivo energy values for different raw materials. As an alternative, the Belgian Institute for Animal Nutrition predicted the energy value (for cattle), calculated from regression equations based on enzymic digestibility. Using samples collected by the feed industry over two years, calibrations were developed on a Technicon IA 500 for 18 raw materials or groups of spectrally related products (De Boever et al. 1993). Equations based on four wavelengths gave satisfactory calibrations for most products with calibration errors (SEC as \% of mean ME value) varying between 1.0 and $2.5 \%$, except for maize gluten feed $(3.0 \%)$, lucerne meal $(3.2 \%)$ and meat and bone meal $(6.8 \%)$. For this latter feed and also for sugar beet pulp the SEC was almost halved when determined ash content was put in the NIR prediction equation. Validation of these calibrations on an independent set of 45 raw materials resulted in an error of $3.4 \%$, which was clearly better than the error of $5.8 \%$ obtained by combining chemical composition and tabular digestion coefficients. Calibrations, made for the 19 filter instruments in the industry, appeared almost equally as good.

Other applications. Tremblay et al. (1996) showed that NIR spectroscopy might be used to predict rumen undegradable protein of whole roasted soyabeans (SEC- and SEP-value of 0.98 and $1.54 \%$ units respectively). Williams et al. (1984) reported that wheat could be screened for the limiting amino acids (AA) lysine, threonine, tryptophan and methionine. In the same paper they mentioned $\mathrm{R}^{2}$ values of more than 0.86 for $13 \mathrm{AA}$ in barley; only for methionine was the explained variance lower (0.66). Coefficients of determination higher than 0.75 were shown for 8 of $11 \mathrm{AA}$ studied in maize and soyabean meal and for 13 of $15 \mathrm{AA}$ in meat and bone meal; with poorer results for methionine, histidine and cystine, and alanine and glutamine respectively (Anon. 1994; Shenk, 1995). Biston (1987) obtained a successful prediction of AA in wheat, oats and field beans. For 45 samples of different raw materials Van Leeuwen et al. (1991) could predict ileal digestibility with an $\mathrm{R}^{2}$ value of 0.081 and an SEC of $4.3 \%$. Harrison et al. (1991) concluded from a study with blood meals that NIR spectroscopy would be feasible to predict lysine digestibility for swine and poultry.

Recently, Van Kempen \& Jackson (1996) demonstrated that calibrations for AA and digestible AA (poultry) for the meat and bone meal, fishmeal and poultry by-products, were better ( $60-90 \%$ of the variance explained) when based on data from all products than on those from the individual animal protein products alone. On the other hand, for products with lower protein levels, such as cereals and oilseed meals, product and product group calibrations performed better than the global database. Further, the global calibrations were found to be reasonably accurate for mixed feeds, but were not able to detect synthetic AA.

Prompted by the need for quality control of fats and oils in the pure form but increasingly originating from destruction, separation and blending, Nutrilab in The Netherlands (A. Waaijenberg, personal communication) developed calibrations on a Technicon IA 450 for moisture + volatile substances, dirt, free fatty acids and iodine value. SEP values amounting to respectively $1 \mathrm{~g} / \mathrm{kg}$ (range: $1-11 \mathrm{~g} / \mathrm{kg}), 2 \mathrm{~g} / \mathrm{kg}(0.5-16 \mathrm{~g} / \mathrm{kg}), 42 \mathrm{~g} / \mathrm{kg}(6-534 \mathrm{~g} / \mathrm{kg})$ and $5 \mathrm{~g} / \mathrm{kg}$ $(49-136 \mathrm{~g} / \mathrm{kg}$ ) were satisfactory at least for screening purposes. Measurement is by transflectance and it is sufficient to preheat a fat sample at $60^{\circ} \mathrm{C}$ and to put a drop in a low volume liquid cell prior to scanning.

In relation to reducing the mineral output by pigs, De Boever et al. (1994b) showed that NIR spectroscopy has potential to predict total and phytate $P$ content in plant based feedstuffs. Considering two spectrally different classes of starchy and protein-rich feedstuffs, the SEP value amounted to $0.08 \%$ for total $P$ in both groups and to 0.08 and $0.04 \%$ respectively for phytate $P$. 
Concerning antinutritive factors, some work has been reported on the prediction of glucosinolates in whole rapeseed. Starr et al. (1985), using an instrument with 19 discrete filters, derived an unacceptably high SEP value of about $30 \mu \mathrm{mol} / \mathrm{g}$. On the other hand, Biston et al. (1987) and Evans et al. (1989), both working with scanning monochromators, obtained much lower SEP of 3 and $6 \mu \mathrm{mol} / \mathrm{g}$ respectively. The latter research revealed that NIR spectroscopy is less accurate at higher concentrations $(>70 \mu \mathrm{mol} / \mathrm{g}$ ), but this may be less of a problem with the recently selected varieties of rape. Since glucosinolates are a group of diverse compounds with different molecular chromophores, it may be expected that NIR spectroscopy would not calibrate well with enzyme methods based on glucose release.

Apart from quantitative purposes, NIR spectroscopy can also be used qualitatively as each raw material shows a characteristic spectral pattern. By means of an equation based on six wavelengths, discriminating between 18 products, De Boever et al. (1993) could correctly identify 42 of 45 raw material samples; the other three were recognized as spectrally related products. This possibility could be interesting as a means of classifying unknown or poorly defined products and detecting outlying samples. Comparing spectra for a so-called conformity analysis may greatly reduce the number of reference analyses (Murray, 1996). Moreover, advanced pattern recognition software can reveal hazards not detected by traditional tests, like heat damaged protein (Cho et al. 1992) and fungal contamination (Roberts, 1992).

\section{Compound feeds}

Compound feeds may contain several, sometimes up to twenty, widely differing feed ingredients supplemented with minerals, vitamins, and possibly enzymes and antibiotics. Because each raw material has its own characteristic spectral pattern due to its chemical and physical properties and there are an infinite number of possible combinations, spectra of compound feeds vary greatly. The presence of differing molecular structures and the varying bulk density and sample surface make spectral interpretation and calibration for a specific nutrient in compound feeds more complicated than in single feeds. Therefore, it is very important to collect a large calibration set, showing maximum attainable variation not only in the parameters to be predicted but also in all likely ingredients to be incorporated and in the proportions likely to be used in future feeds-commercially prepared feeds should be used rather than artificial mixtures. Further, variability can be reduced by considering separate calibrations for the different animal species and even within a species for different types of production or supplementation. In Table 11 a survey of published work is shown on the use of NIR spectroscopy to predict the chemical composition and the energy value of compound feeds and includes reference to: type of instruments i.e. scanning monochromator (SM), tilting (TF) or fixed filters (FF); the number and the nature of the samples; the calibration (SEC) and/or validation error (SEP).

Chemical composition. Compared with the calibrations to predict the chemical composition of raw materials (p. 100), those for compound feeds are generally somewhat less accurate. Considering absolute contents, Table 11 indicates that the SEC/P is lower and less varying for moisture (range: $2-7 \mathrm{~g} / \mathrm{kg}$ ) and crude fat (1-8 g/kg DM) than for crude protein (4-15 g/kg DM), crude fibre (3-19 $\mathrm{g} / \mathrm{kg} \mathrm{DM})$ and crude ash (2-15 $\mathrm{g} / \mathrm{kg} \mathrm{DM})$. These differences can be explained by several factors, the most important being the nature and the reference method of the chemical fraction, the composition of the calibration set, the type of instrument and modelling method. Compared with moisture and fat, molecular vibrations associated with crude protein and crude fibre are more complex. Crude protein in compound feeds is calculated from 
$\mathrm{N} \times 6.25$, wrongly assuming a constant true protein content. Williams \& Starkey (1980) showed that incorporation of urea, a common practice in cattle feeds, may have a distinct effect on NIR spectra and recommended making separate calibrations for compound feeds with and without added non-protein nitrogen. Even more than crude protein, the crude fibre content of compound feeds may have a very complex molecular composition, as it is composed of mainly cellulose and varying amounts of hemicellulose and lignin. Hence, it is understandable that calibrations for ruminant compound feeds, which can utilize a larger range of fibrous raw materials, show higher errors than those for monogastric feeds. For the latter, the variation in the calibration set was narrowed still further by Chen et al. (1987) and Pazourek \& Cerny (1988) who examined respectively five and three production categories of pig feeds, Gerlach (1990) treating layer and broiler feeds separately, and Van Lonkhuijsen \& Jansen (1987) excluding sow feeds. The prediction of crude protein and particularly crude fibre can also be improved by using NIR spectrometers with more wavelength capabilities (Charles \& Shenk, 1986; De Boever et al. 1995).

Finally, De Boever (unpublished) found that whole spectrum calibration models like PLS are better than those based on a few wavelengths selected by multiple linear regression. Although calibrations for crude ash show similar SEC/P values to crude protein and fibre, the correlation with the reference method is usually much lower. NIR spectroscopy fails when large amounts of inorganic minerals are added, as in feeds for layers (Gerlach, 1990). The response of NIR spectroscopy to minerals can only be explained through their association with organic molecules, as was shown for P in plant based feedstuffs (De Boever et al. 1994b) and for Ca and $P$ in poultry feeds (Valdes et al. 1985). Considering the legal tolerances for moisture, crude protein, crude fibre, crude fat and crude ash, De Boever et al. (1995) found respectively 0, 6, 10,3 and 30 of 163 commercial compound feeds were wrongly predicted by NIR spectroscopy. The multivariate statistics will provide an $\mathbf{H}$-statistic which warns when a sample is not represented in the calibration set, and De Boever et al. (1995) concluded that inspection services could use the technique as a screening method for chemical composition with the exception of ash, restricting wet chemical analyses to samples that do not conform with the declaration on the label.

Besides the Weende composition, only a few studies examined other chemical parameters. The limited study of Murray \& Hall (1983) with ruminant feeds and recently Aufrère et al. (1996) with cattle and pig feeds showed good results for starch, neutral detergent fibre and acid detergent fibre and moderate results for lignin and sugars. This was confirmed for starch by Van Lonkhuijsen \& Jansen (1987), for neutral detergent fibre by De Boever et al. (1995) and for acid detergent fibre by Flinn \& Murray (1992).

Energy value. As a consequence of the laborious and time consuming procedures used to determine energy value there are insufficient in vivo reference data to make robust NIR spectroscopy calibrations. In Table 11 the few studies published are summarized. Because of the different ways of expressing energy value, the SEC/P values are given as percent of the mean energy content of the calibration samples. The studies, including the 163 cattle feeds in De Boever et al. (1995), were not all based on in vivo experiments but some also on in vitro digestibility with either rumen fluid (Flinn \& Murray, 1992) or commercial enzymes (Verheggen et al. 1990). Although in vitro values already contain a prediction error, De Boever et al. (1995) proved that calibrations based on in vitro reference data were only slightly less accurate than those based on in vivo data. In vitro methods, however, offer the advantage that a greater number of samples can be analysed and that the results are more reproducible. The tendencies that can be observed from Table 11 are similar to those already discussed for 
The principles, practice and some future applications of near infrared spectroscopy

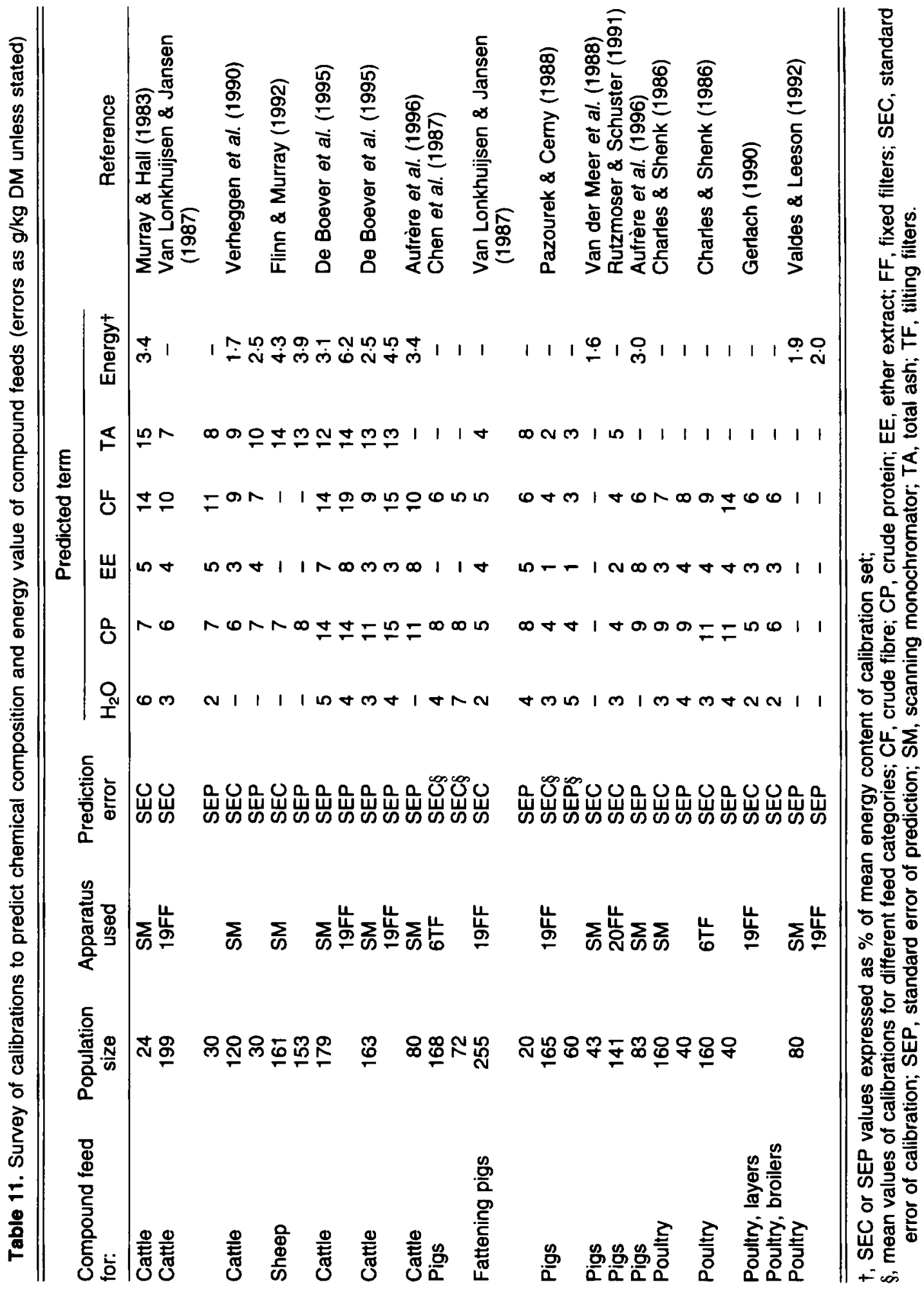


crude protein and crude fibre. NIR spectroscopy performs better for monogastric than for ruminant feeds and better with scanning than with filter instruments.

Other applications. It is obvious that NIR spectrometers can be exploited optimally only if they are implemented as on-line, closed loop units. Two different systems, both developed in Denmark, are currently used in the animal feed industry (Jensen, 1993). The Prinacon system, introduced in 1988, controls nutrients in all major raw materials as they enter the manufacturing process, thus enabling production according to least cost optimization at all times. The Formal system, on the market since 1991, measures the manufactured feed shortly after the end of the mixing step in the process line and adds high grade protein, fat or moisture accordingly. In both systems samples are automatically taken, transported, milled and presented to the NIR spectrometer units.

For the moment, NIR spectroscopy analysis in the feed industry requires milling of the samples. Recently, instruments have been developed with moving or rotating sample cups and a larger presentation area allowing measurements in either reflectance or transmittance mode on unmilled products like whole grains or pellets. For the gain in time some loss in accuracy has to be accepted (Leterme et al. 1990; Shenk, 1992), with reflectance appearing equal to or more accurate than transmittance (Williams \& Sobering, 1992).

\section{Application to human food}

The applications of NIR spectroscopy to food and drink analysis are widespread and it is not the intention in this review to cover all of these in detail. There are a number of detailed reviews to which the reader is referred, including those of Davies \& Grant (1987), Varadi (1991) and Osborne et al. (1993a). Table 12 gives an overview of selected reported applications of NIR spectroscopy in relation to different foods and drinks. This table indicates that determinations of water, protein, fat, sucrose and starch account for the majority of the applications.

\section{Prediction of the nutritive value of food}

\section{Water}

The determination of water was the first application of NIR spectroscopy in the analysis of food. Calibrations have been developed for estimating the water content of a wide range of foods including barley, bread, cheese, meat, milk powder and potato crisps. Osborne et al. (1993a) reported that almost all of these calibrations used the $1940 \mathrm{~nm}$ wavelength region as the primary measurement, this being a combination NIR absorption band for water involving $\mathrm{O}-\mathrm{H}$ stretch and $\mathrm{O}-\mathrm{H}$ bend vibrations. Water has also been estimated in foods such as meat (Norris, 1983) and cereal grains (Williams \& Cordeiro, 1985) by NIR transmittance spectroscopy, usually in the short $(800$ to $1100 \mathrm{~nm})$ wavelength part of the NIR region.

\section{Protein}

NIR spectroscopy has been used to predict the protein content of many food constituents, including cereal grains, bread, cheese, egg products, malt, peas, fish, rice and whey powder. Historically, the determination of protein in wheat was by far the most important application, not least because this approach allowed large numbers of samples to be examined cheaply. In addition it gave the milling industry the opportunity to screen deliveries of wheat quickly, 


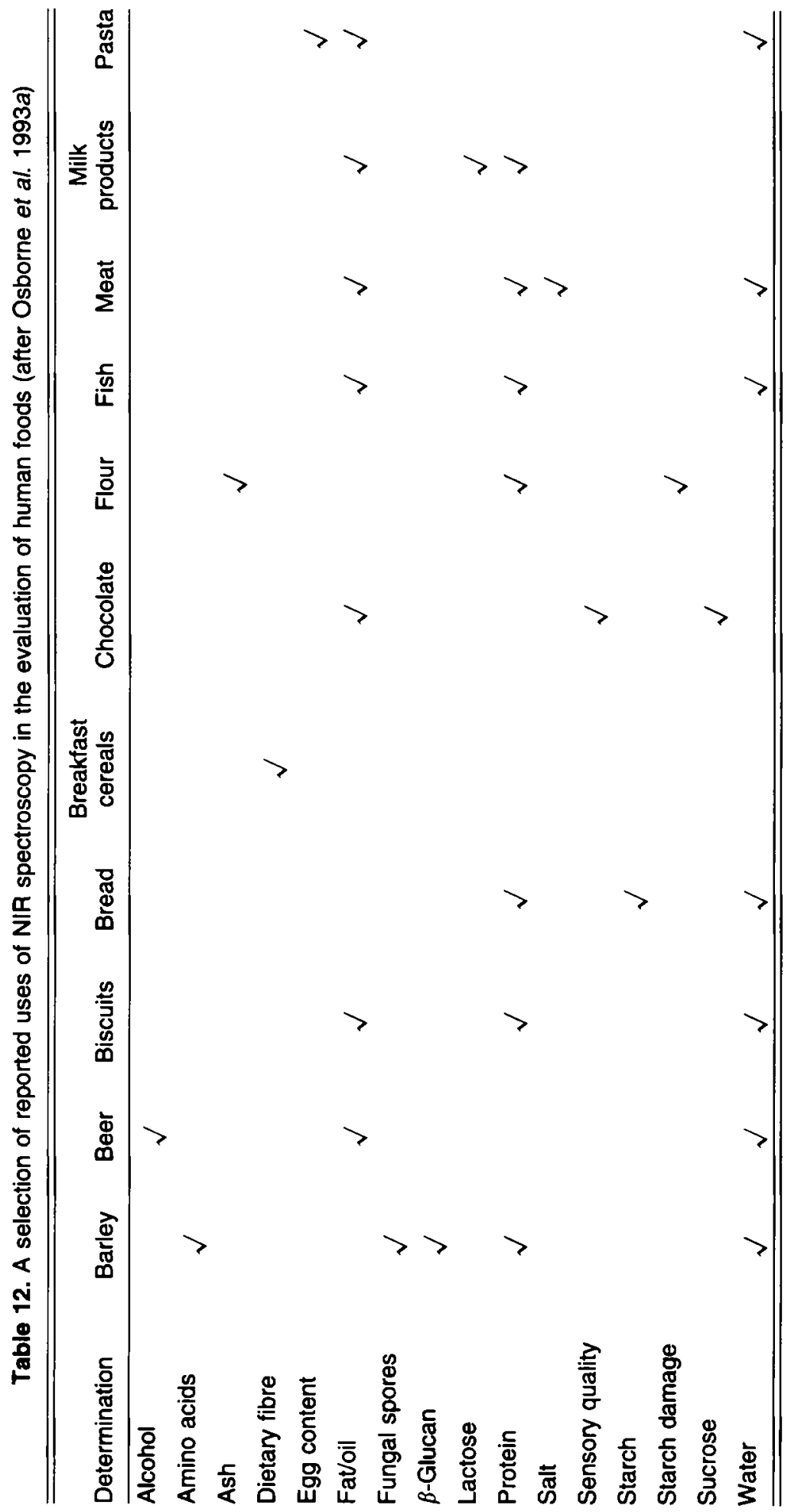


enabling rapid decisions to be made about the suitability of the consignment. Protein determination by NIR spectroscopy is also undertaken for barley and oats and by millers to monitor the protein content of flour.

Fat

Like protein, NIR spectroscopy has been used to predict the fat content of a wide range of foods. According to Osborne et al. (1993a), the major NIR absorption bands in fats and oils are due to the long chain fatty acids which give rise to a $\mathrm{CH}_{2}$ second overtone at $1200 \mathrm{~nm}, \mathrm{CH}_{2}$ first overtones at 1734 and $1765 \mathrm{~nm}$ and $\mathrm{CH}_{2}$ stretch bend combinations at 2310 and $2345 \mathrm{~nm}$. Unsaturated bonds in some fatty acids also exhibit other absorption bands enabling NIR spectroscopy to predict the degree of unsaturation of a fat source.

\section{Carbohydrates}

Carbohydrates in foods represent a very wide range of components, from monosaccharides such as glucose and disaccharides such as sucrose to starches and dietary fibre. All have similar NIR spectra although subtle differences do exist (Osborne et al. 1993a; Deaville \& Givens, 1997) and the determination of glucose, sucrose and fructose has been reported in fruit juices together with sucrose in wine, chocolate and baked foods (Osborne et al. 1993a).

A considerable amount of effort has gone into the use of NIR spectroscopy for predicting the various dietary fibre fractions in foods. For example, calibrations have been reported for total dietary fibre in bread (Osborne et al. 1993a), wheat bran and carrots (Horvath et al. 1985) and oat bran (Williams et al. 1991). Williams et al. (1991) also reported a calibration for soluble dietary fibre in oat bran. Soluble fibre in oats is primarily made up of $\beta$-glucans, which are regarded as beneficial to health because of their hypocholesterolaemic effects (see review of Welch, 1988). It is however also believed that the propensity of $\beta$-glucans to form gels in aqueous media is responsible for the excretion of sticky droppings by poultry when fed oats and other cereals (McNab \& Smithard, 1992), and for difficulties in filtration in the malting process. Because of the latter, barley is screened by NIR spectroscopy (e.g. Henry, 1985) during breeding programmes to select for low $\beta$-glucan content.

\section{Use of NIR spectroscopy in food processing}

A considerable amount of research has been undertaken into the use of NIR spectroscopy for monitoring changes in food components during processing. For example, Osborne et al. (1990) showed that NIR spectroscopy could be used to follow the progress of bread staling, and more recently Cho et al. (1995) showed that it could be used to identify the denaturation process and to analyse structural changes of proteins in foods denatured during high pressure cooking.

Two of the most important attributes of meat are its protein content and taste after cooking. Although the protein content of individual muscles varies considerably there are also substantial differences in the protein content of carcasses from the same animal species. To improve the value of the carcass to the meat trade the Danish Meat Research Institute developed a project aimed at predicting the protein content of the lean meat in pigs while they were still on the slaughter line. Andersen (1990) reported that NIR spectroscopy using fibre optic probes appeared to provide a feasible means of doing this, although he also proposed that more work was needed on the use of NIR spectroscopy with unhomogenized samples. More recently it has also been shown by Hildrum et al. (1995) that NIR spectroscopy may be used to predict sensory and textural properties of meat such as hardness, tenderness and juiciness. They 
concluded however that more work was needed before the relationships could be used for a practical meat tenderness scheme.

\section{Use of NIR spectroscopy for food authentication}

The feasibility of using NIR spectroscopy to discriminate between different food sources has opened up many possible applications for the technique. For example, Scotter (1993) reported how discriminant analysis of NIR spectra was used to differentiate various types of orange juice. Samples were dried on to glass fibre disks and scanned. Canonical variate analysis was used to compress the principal components, which allowed identification of authentic from aduiterated juice. Similarly, Osborne et al. (1993b) successfully used PCA and linear discriminant functions to distinguish nine samples of Basmati rice from 53 other samples of long grain rice. More recently Krzanowski (1995), using the same NIR spectral data, examined the multivariate techniques of PLS, orthogonal canonical variates and a recently proposed search for 'extremeness' and demonstrated complete support for the earlier findings. The use of discriminant analysis in this way opens up many possibilities in relation to authentication of foods and to the enforcement of related legislation.

\section{Conclusions and future prospects}

NIR spectroscopy has revolutionized the analysis and nutritional evaluation of animal feeds and human foods by providing a rapid means of examination. This has had, and will continue to have, substantial and widespread implications. For example, the trade in raw materials and compound animal feeds is subject to national and international legislation to safeguard humans, animals and the environment and to ensure an honest and competitive market. However, there are serious doubts as to which method is adequate as well as practical for all interested partners, i.e. the industry, customs and official laboratories and the research community acting for the benefit of the farmers. The present review provides the evidence that NIR spectroscopy has the potential to fill this gap. Similar approaches are already being used to authenticate the quality and origin of human foods and it is certain that this will increase in the future. Thus, apart from quantitative purposes, NIR spectroscopy can also be used as a qualitative tool for identity control. This could be very attractive for inspection services to trace adulterated and contaminated products.

For small and medium sized feed and food manufacturing companies NIR spectroscopy is better than the current use of tables of nutritional values or expensive analyses in external laboratories. For large companies the technique also offers many advantages compared with cumbersome and time consuming wet chemical analyses. Its rapidity allows more frequent measurements at all stages from the purchase of raw materials and ingredients to the control of the finished product. Because sample preparation is limited to milling, or may not be required at all with recently developed whole grain analysers, the technique is well suited to in-line use. Another advantage is that multi-analytical results give a total view of the quality. Up to now the practical use of NIR spectroscopy has been mainly restricted to filter instruments predicting major organic nutrients. Research has also shown potential for more complex parameters such as digestibility, energy value, amino acids, fatty acids, dietary fibre and even minor constituents like $\beta$-glucans and glucosinolates. However, this potential can only be fully exploited in 
practice when more extended databases become available and instruments with more wavelength and data processing capacities are used.

NIR spectroscopy has also revolutionized the nutritional characterization of forages. This is extremely important since, world-wide, human food production from ruminants is highly dependent on efficient utilization of forages. NIR spectroscopy has facilitated rapid evaluation of forages thus allowing strategic and economic decisions to be made regarding supplementation or forage upgrading. Characterization of forages and other animal feeds is undergoing very substantial changes with much greater emphasis being placed on estimating the nutrients available to the animal rather than estimating all-embracing values such as energy and protein. Such approaches will require complex methods of evaluation in the future and it seems likely that they could only be put into practice if they can be predicted by NIR spectroscopy.

NIR spectroscopy has therefore made a very substantial impact in the last 10-20 years. Its role will undoubtedly increase, and with growing pressure to produce food economically and with minimum environmental impact for an increasing world population it is likely that NIR spectroscopy and its allied sciences will be indispensable.

\section{References}

Abrams, S. M., Shenk, J. S. \& Harpster, H. W. (1988). Potential of near infrared reflectance spectroscopy for analysis of silage composition. Joumal of Dairy Science 71, 1955-1959.

Andersen, J. R. (1990). Rapid NIR protein assay in unhomogenised meats. In International Symposium on Near Infrared (NIR) Spectroscopy used in the Food and Feed Industry, pp. 66-69. Kolding: Bioteknisk Institut.

Aufrère, J., Graviou, D., Demarquilly, C., Perez, J. M. \& Andrieu, J. (1996). Near infrared refiectance spectroscopy to predict energy value of compound feeds for swine and ruminants. Animal Feed Science and Technology 62, 77-90.

ADAS (1989). The nitrogen value of grass silage. ADAS Feed Evaluation Unit Technical Bulletin 89/10, 4 pp. Stratfordupon-Avon: ADAS.

AFRC (1991). AFRC Technical Committee on Responses to Nutrients, Report Number 8. Voluntary intake of cattle. Nutrition Abstracts and Reviews B 61, 815-823.

AFRC (1992). AFRC Technical Committee on Responses to Nutrients. Report No. 9. Nutritive Requirements of Ruminant Animals: Protein. Nutrition Abstracts and Reviews B 62, 787-835.

Anon. (1994). How accurately can NIRS measure amino acids in ingredients? Feed International 15 (10), 20.

Baker, C. W. \& Barnes, R. J. (1990). The application of near infrared spectroscopy to forage evaluation in ADAS. In Feedstuff Evaluation (Nottingham Easter School in Agricultural Science no.50, 1989), pp. 337-351 [J. Wiseman and D. J. A. Cole, editors]. London: Butterworths.

Baker, C. W., Givens, D. I. \& Deaville, E. R. (1994). Prediction of organic matter digestibility in vivo of grass silage by near infrared reflectance spectroscopy. Effect of calibration method, residual moisture and particle size. Animal Feed Science and Technology 50, 17-26.

Barber, G. D., Givens, D. I., Kridis, M. S., Offer, N. W. \& Murray, I. (1990). Prediction of the organic matter digestibility of grass silage. Animal Feed Science and Technology 28, 115-128.

Barber, G. D., Offer, N. W. \& Givens, D. I. (1989). Predicting the nutritive value of silage. In: Recent Advances in Animal Nutrition-1989, pp. 141-158 [W. Haresign and D. J. A. Cole, editors]. London: Butterworths.

Bames, R. J., Dhanoa, M. S. \& Lister, S. J. (1989). Standard normal variate transformation and de-trending of nearinfrared diffuse reflectance spectra. Applied Spectroscopy 43, 772-777.

Beever, D. E. \& Reynolds. C K. (1994). Forage quality, feeding value and animal performance. In Grassland and Society, Proceedings of the European Grassland Federation, pp. 48-60.

Ben-Gera, I. \& Norris, K. H. (1968). Direct spectrophotometric determination of fat and moisture in meat products. Joumal of Food Science 33, 64-67.

Bertrand, D., Robert, P. \& Devaux, M.F. (1992). Trends in analytical applications of NIR spectroscopy. In Near Infrared Spectroscopy. Bridging the Gap between Data Analysis and NIR Applications, pp. 165-172 [K. I. Hildrum, T. Isaksson, T. Næs and A. Tandberg, editors]. London: Ellis Horwood.

Biston, R. (1987). [Methodology and potential of near infrared reflectance analysis.] Seminar organised by Dickey John, no. 9, pp. 24.

Biston, R., Dardenne, P., Cwikowski, M., Wathelet, J. P. \& Severin, M. (1987). Analysis of quality parameters of whole rapeseed by NIRS. In Glucosinolates in Rapeseeds: Analytical Aspects, pp. 163-172 [J. P. Wathelet, editor]. Dordrecht, The Netherlands: Martinus Nijhoff. 
Charles, O. W. \& Shenk, J. S. (1986). Further studies of near infrared diffusion reflectance spectroscopy. Proceedings of the Georgia Nutrition Conference for the Feed Industry, pp.112-120.

Chen, S.-L.Y., Hsu, A. \& Lee, M.-L. (1987). Application of near infrared reflectance spectroscopy to compositional analysis of commercial pig feed mixes. Joumal of the Association of Official Analytical Chemists 70, $420-423$.

Choi, R. K., Lee, J. H., Ahn, J. J., Ozaki, Y. \& Iwamoto, M. (1995). The applicability of near infrared reflectance spectroscopy for determining solubility and digestibility of heated protein under high pressure. Joumal of Near Infrared Spectroscopy 3, 73-80.

Cho, R. K., Ozaki, Y., Ahn, J. J. \& Iwamoto, M. (1992). The application of near infrared reflectance spectroscopy for monitoring changes in secondary structure of denatured proteins. In: Near Infrared Spectroscopy. Bridging the Gap beiween Data Analysis and NIR Applications, pp 333-338 [K. I. Hildrum, T. Isaksson, T. Næs and A. Tandberg. editors]. London: Ellis Horwood.

Clark, D. H. \& Lamb, R. C. (1991). Near infrared reflectance spectroscopy. A survey of wavelength selection to determine dry matter digestibility. Journal of Dainy Science 74, 2200-2205.

Coelho, M., Hembry, F. G., Saxton, A. M. \& Barton, F. E. (1988). A comparison of microbial, enzymatic, chemical and near infrared reflectance spectroscopy methods in forage evaluation. Animal Feed Science and Technology 20, 219231.

Cone, J. W., van Gelder, A. H., Visscher, G. J. W. \& Oudschoom, L. (1996). Influence of rumen fluid and substrate concentration on fermentation kinetics measured with a fully automated time related gas production apparatus. Animal Feed Science and Technology 61, 113-128.

Cowe, I. A. \& McNicol, J. W. (1985). The use of principal components in the analysis of near-infrared spectra. Applied Spectroscopy 39, 257-266.

Dardenne, P., Sinnaeve, G., Bollen, ?., \& Biston, R. (1995). Reduction of wet chemistry for NIR calibrations. In Leaping Ahead with Near Infrared Spectroscopy, pp. 154-160 [G. D. Batten, P. C. Flinn, L. A. Walsh and A. B. Blakeney, editors].

Davies, A. M. C. \& Grant, A. (1987). Review. Near infrared analysis of food. Intermational Journal of Food Science and Technology 22, 191-207.

Deaville, E. R. \& Baker, C. W. (1993). Spectral interpretations in relation to feed characterisation. In Proceedings of ADAS Drayton Feed Evaluation Unit Conference, NIRS Developments in Agriculture and Food, $20 \mathrm{pp}$. Oxford: ADAS.

Deaville, E. R. \& Givens, D. I. (1996a). Prediction of the non-fermentable energy fraction of grass silage using near infrared reflectance spectroscopy. Animal Science 60, 681(Abstr.).

Deaville, E. R. \& Givens, D. I. (1996b). Prediction of the non-fermentable energy fraction of grass silage by nearinfrared reflectance spectroscopy. Animal Science 62, 681(Abstr.).

Deaville, E. R. \& Givens, D. I. (1997). Regions of normalised near infrared reflectance difference spectra related to the rumen degradation of fresh grass, grass silage and maize silage (submitted for publication).

Deaville, E.R., Givens, D.I. \& Baker, C.W. (1992). Use of normalised NIR difference spectra to identify regions related to digestion of cell walls in straws. In Near Infrared Spectroscopy, pp. 219-222 [K. L. Hildrum, T. Isaksson, T. Naes and A. Tandberg, editors]. Chichester: Ellis Horwood Ltd.

De Boer, F. \& Bickel, H. (1988). Impact of feed in livestock production. Livestock Production Science 19, 3-10.

De Boever, J. L., Cottyn, B. G., De Brabander, D. L., Vanacker, J. M. \& Boucqué, Ch. V. (1996). Prediction of the feeding value of grass silages by chemical parameters, in vitro digestibility and near-infrared reflectance spectroscopy. Animal Feed Science and Technology 60, 103-115.

De Boever, J. L., Cottyn, B. G., Vanacker, J. M. \& Boucqué, Ch. V. (1993). Recent developments in the use of NIRS for evaluating compound feeds and raw materials for ruminants. In Proceedings of ADAS Drayton Feed Evaluation Unit Conference, NIRS Developments in Agriculture and Food, 11 pp. Oxford: ADAS.

De Boever, J. L., Cottyn, B. G., Vanacker, J. M. \& Boucqué, Ch. V. (1994a). An improved enzymatic method by adding gammanase to determine digestibility and predict energy value of compound feeds and raw materials for cattle. Animal Feed Science and Technology 47, 1-18.

De Boever, J. L., Cottyn, B. G., Vanacker, J. M. \& Boucqué, Ch. V. (1995). The use of NIRS to predict the chemical composition and the energy value of compound feeds for cattle. Animal Feed Science and Technology 51, $243-253$.

De Boever, J. L., Eeckhout W. \& Boucqué, Ch. V. (1994b). The possibilities of near infrared reflection spectroscopy to predict total-phosphorus, phytate-phosphorus and phytase activity in vegetable feedstuffs. Netherlands Joumal of Agricultural Science 42, 357-369.

Debry, G. (1992). [Evolution of concepts in human nutrition]. In Alimentation et Nutrition Humaines, pp. 67-83 [H. Dupin, J.-L. Cuq, M.-I. Malewiak, C. Leynaud-Rouaud and A.-M. Berthier, editors]. Paris: ESF.

De Vries, P. F. \& De Jong. J. (1991 [Quality assurance with NIR analysis]. Kraftfutter no.9, 392, 394.

Dijkstra, J. (1993). Mathematical modelling and integration of rumen fermentation processes. Doctoral Thesis, Agricultural University, Wageningen, The Netherlands, $221 \mathrm{pp}$.

Eschenauer, U., Henck, O., Hühne, M., Wu, P., Zebger, I. \& Siesler, H.W. (1992). Near-infrared spectroscopy in chemical research, quality assurance and process control. In Near Infra-red Spectroscopy. Bridging the Gap between Data Analysis and NIR Applications, pp. 11-18 [K. 1. Hildrum, T. Isaksson, T. Næs and A. Tandberg, editors]. London: Ellis Horwood.

Evans, E. J., Bilsborrow, P., Grant, A, Kwiatkowska, C. A., Spinks, E. A., Heaney, R. K. \& Fenwick, G. R. (1989). A comparison of rapid (X-ray fluorescence, near-infrared reflectance) and glucose-release methods for the determina- 
tion of the glucosinolate content of oilseed rape (Brassica oleracea). Joumal of the Science of Food and Agriculture 49, 297-305.

Flinn, P.C. \& Murray, I. (1992). Sample, instrumental and seasonal influences on the performance of NIR calibrations in feed analysis. In Making Light Work Advances in Near Infrared Spectroscopy, pp. 253-263 [I. Murray and I. A. Cowe, editors]. Weinheim: VCH.

Flinn, P. C., Windham, W. R. \& Dove, H. (1992). Pasture intake by grazed sheep estimated using natural and dosed n-alkanes - a place for NIR? In Near Infrared Spectroscopy. Bridging the Gap between Data Analysis and NIR Applications, pp. 175-178 [K. L. Hildrum, T. Isaksson, T. Naes and A. Tandberg, editors]. Chichester: Ellis Horwood Ltd.

Foulkes, G. R. (1993). Cell wall digestion kinetics. M. Phil. Thesis, University College of Wales, Aberystwyth, $110 \mathrm{pp}$

Gerlach, M. (1990). [NIR measuring technology for quality evaluation of feeds.] Kraftfutter, no. 2, 67-74.

Giger-Reverdin, S., Aufrère, J., Sauvant, D., Demarquilly, C. \& Vermorel, M. (1994). Prediction of the energy values of compound feeds for ruminants. Animal Feed Science and Technology 48, 73-98.

Givens, D. I., Baker, C. W., Adamson, A. H. \& Moss, A. R. (1992a). Influence of growth type and season on the prediction of the metabolisable energy content of herbage by near infrared reflectance spectroscopy. Animal Feed Science and Technology 37, 281-296.

Givens, D. I., Baker, C. W. \& Zamime, B. (1992b). Regions of normalised near infrared reflectance difference spectra related to the rumen digestion of straws. Animal Feed Science and Technology 36, 1-12.

Guzmán, J. L., Garrido, A., Gómez-Cabrera, A., Guerrero, J. E. \& Murray, I. (1996). Use of NIRS to estimate the improvement in digestibility after ammonia treatment of cereal straws. Animal Feed Science and Technology 57, $149-157$.

Hacker, J. B. (1981). Selecting and breeding better quality grasses. In Nutritional Limits to Animal Production from Pastures (International Symposium Queensland), pp. 305-326 [J. B. Hacker, editor]. Farnham Royal: Commonwealth Agricultural Bureaux.

Harrison, M. D., Ballard, M. R. M., Barclay, R. A., Jackson, M. E. \& Stilborn, H. L. (1991). A comparison of true digestibility for poultry and apparent ileal digestibility for swine. A classical in vitro method and NIR spectrophotometry for determining amino acid digestibility. In: Digestive Physiology in Pigs (International Symposium no. 5; EAAP Publication no. 54), pp. 254-259 [M. W. A. Verstegen, J. Huisman and L. A. den Hartog, editors]. Wageningen, The Netherlands: Pudoc.

Henry, R. J. (1985). Evaluation of barley and malt quality using near infrared reflectance techniques. Joumal of the Institute of Brewing 91, 393-396.

Herrero, M., Murray, I., Fawcett, R. H. \& Dent, J. B. (1996). Prediction of the in vitro gas production and chemical composition of kikuyu grass by near-infrared reflectance spectroscopy. Animal Feed Science and Technology 60 , $51-67$.

Hildrum, K. I., Isaksson, T., Næs, T., Nilsen, B. N., Rodbotten, M. \& Lea, P. (1995). Near infrared refiectance spectroscopy in the prediction of the sensory properies of beef. Joumal of Near Infrared Spectroscopy 3, 81-88.

Horvath, L. Norris, K. H. \& Horvath-Mosonyi, M. (1985). Comparative investigations into the determination of protein by the Kjeldahl method and NIR technique. Acta Alimentaria 14, 113-124.

Hunt, W. H., Fulk, D. W., Elder, B. \& Norris K. (1977). Collaborative study on infrared reflectance devices for determination of protein in hard red winter wheat, and for protein and oil in soybeans. Cereal Foods World 22, 534 536.

Iwamoto, M. \& Kawano, S. (1992). Advantages and disadvantages of NIR applications for the food industry. In Making Light Work: Advances in Near Infrared Spectroscopy, pp. 367-375 [I. Murray and I. A. Cowe, editors]. Weinheim: VCH.

Jensen, E. P. (1993). Use of NIR for on-line process control during the manufacture of animal feedstuffs. In Proceedings of ADAS Drayton Feed Evaluation Unit Conference, NIRS Developments in Agriculture and Food, 8 pp. Oxford: ADAS.

Krzanowski, W. J. (1995). The authentication of Basmati rice using near infrared spectroscopy: some further analysis. Journal of Near Infrared Spectroscopy 3, 111-117.

Kridis, M. S. F. (1989). Energy evaluation of grass silage. PhD. Thesis, University of Glasgow and West of Scotland College, Ayr. 302 pp.

Leterme, P., Dardenne, P., Théwis, A. \& Biston, R. (1990). Protein and crude fibre determination on triticale. NIR and NIT comparison. In Proceedings of the Third Intemational Conference on Near Infrared Spectroscopy, pp. 558-560 [R. Biston and N. Bartiaux-Thill, editors]. Gembloux, Belgium: Agricultural Research Centre.

Lindgren, E. (1983). The use of near infrared reflectance spectroscopy for predicting energy value of grass. Swedish Journal of Agricultural Research 13, 229-233.

Lindgren, E. (1988). Prediction of energy value and protein content of forages by near infrared reflectance spectroscopy. Swedish Journal of Agricultural Research 18, 21-26.

McNab, J. M. \& Smithard, R. R. (1992). Barley $\beta$-glucan: an antinutritional factor in poultry feeding. Nutrition Research Reviews 5, 45-60.

MAFF (1993). Prediction of the energy values of compound feedingstuffs for farm animals. London: MAFF Publications, 17pp.

Manne, R. (1987). Analysis of two partial least squares algorithms for multivariate calibration. Chemometrics and Intelligent Laboratory Systems 2, 187-197. 
Mayes, R. W., Lamb, C. S. \& Colgrove, P. M. (1986). The use of dosed and herbage n-alkanes as markers for the determination of herbage intake. Journal of Agricultural Science 107, 161-170.

Menke, K. H., Raab, L., Salewski, A., Steingass, H., Fritz, D. \& Schneider, W. (1979). The estimation of the digestibility and metabolizable energy content of ruminant feedingstuffs from the gas production when they are incubated with rumen liquor in vitro. Journal of Agricultural Science 93, 217-222.

Minson, D. J. (1982). Effects of chemical and physical composition of herbage eaten upon intake. In Nutritional Limits to Animal Production for Pastures (Intemational Symposium, Queensland), pp. 167-182. [J. B. Hacker, editor]. Farnham Royal: Commonwealth Agricultural Bureaux.

Moya, L., Garrido, A., Guerrero, J.E., Lizaso, J. \& Gomez, A. (1995). Quality control of raw materials in the compound feed industry. In Leaping Ahead with Near Infrared Spectroscopy, pp. 111-116 [G. Batten, P. C. Flinn, L. A. Welsh and A. B. Blakeney, editors]. Melbourne: Royal Australian Chemical Institute.

Murray, I. (1993). Forage analysis by near infrared reflectance spectroscopy. In: Sward Management Handbook, pp. 285-312 [A. Davies, R. D. Baker, S. A. Grant and A. S. Laidlaw, editors]. Reading: British Grassland Society.

Murray, I. (1996). The value of traditional analytical methods and near-infrared (NIR) spectroscopy to the feed industry. In Recent Advances in Animal Nutrition, pp. 87-110. [P. C. Garnsworthy and D. J. A. Cole, editors]. Nottingham: Nottingham University Press.

Murray, I. \& Hall, P. A. (1983). Animal feed evaluation by use of near infrared reflectance (NIR) spectrocomputer. Analytical Proceedings 20, 75-79.

Murray, I., Kridis, M. S. F., Barber, G. D., Givens, D. I. \& Offer, N. W. (1987). Grass silage in vivo digestibility prediction by NIR. CEC Monograph. Brussels.

Noblet, J., Fortune, H., Shi, X. J. \& Dubois, J. (1994). Prediction of net energy value of feeds for growing pigs. Joumal of Animal Science 72, 344-354.

Norris, K. H. (1983). Multivariate analysis of raw materials. In Chemistry and World Food Supplies: The New Frontiers. Chemrawn II, pp. 527-535 [W. L. Shemilt, editor]. Pergamon Press.

Norris, K. H. (1989). Definition of NIRS analysis. In Near Infrared Reflectance Spectroscopy (NIRS): Analysis of Forage Quality, USDA-ARS Agriculture Handbook no. 643, pp. 6 [G. C. Marten, Shenk, J. S. and F. E. Barton II, editors]. Washington, DC: USDA.

Norris, K. H. (1992). Early history of near infrared for agricultural applications. NIR News 3, 12-13.

Norris, K. H., Barnes, R. F., Moore, J. E. \& Shenk, J. S. (1976). Predicting forage quality by infrared reflectance spectroscopy. Journal of Animal Science 43, 889-897.

Norris, K. H. \& Butler, W. L. (1961). Techniques for obtaining absorption spectra on intact biological samples. IRE Transactions on Biomedical Electronics 8, 153-157.

Norris, K. H. \& Hart J. R. (1965). Direct spectrophotometric determination of moisture content of grain and seeds. Principles and Methods of measuring Moisture Content in Liquids and Solids 4, 19-25.

Norris, K. H. \& Williams, P. C. (1979). The determination of protein and moisture in HRS wheat by near-infrared reflectance spectroscopy I. A comparative study of 12 instrumental methods. Cereal Foods World 24, 459 (Abstr.).

Offer, N. W. (1993). Background to the new in vivo ME silage prediction equation. In: Proceedings of Society of Feed Technologists Ruminants Conference, pp. El-E7. Reading: Society of Feed Technologists.

Osborne, B. G. \& Fearn. T. (1986). Near Infrared Spectroscopy in Food Analysis, 200 pp. Harlow: Longman Group.

Osborne, B. G., Fearn, T. \& Hindle, P. H. (1993a). Practical NIR Spectroscopy with Applications in Food and Beverage Analysis, 227 pp. Harlow: Longman Scientific and Technical.

Osborne, B. G., Mertens, B., Thompson, M. \& Feam, T. (1993b). [The authentication of Basmati rice using near infrared spectroscopy.] Journal of Near Infrared Spectroscopy 1, 77-83.

Osborne, B. G., Oliver, G. \& Russell, P. L. (1990). The application of near infrared reflectance spectroscopy to the study of the staling of bread. In Proceedings of the Third International Conference on Near Infrared Spectroscopy, pp. 207-212 [R. Biston and N. Bartiaux-Thill, editors]. Gembloux: Agricultural Research Centre Publishing.

Pazourek, K. \& Cerny, M. (1988). Application of near infrared reflectance technique in the analysis of selected pig feed mixes. Acta Alimentaria 17, 113-125.

Robert, P., Bertrand, D. \& Demarquilly, C. (1986). Prediction of forage digestibility by principal component analysis of near infrared reflectance spectra. Animal Feed Science and Technology 16, 215-224.

Roberts, C. A. (1992). Quantification of fungal contaminants in forage and grain. In Making Light Work: Advances in Near Infrared Spectroscopy, pp. 367-375 [I. Murray and I. A. Cowe, editors]. Weinheim: VCH.

Russell, J. D., Murray, I. \& Fraser, A. R. (1989). Near- and mid-infrared studies of the cell wall structure of cereal straw in relation to its rumen degradability. In Physico-Chemical Characterisation of Plant Residues for Industrial and Feed Use (Workshop, Aberdeen, 1988), pp. 13-24. [A. Chesson and E. R. Ørskov, editors]. London: Elsevier Applied Science.

Rutzmoser, K. \& Schuster, M. (1991). [Determination of crude nutrients' content in farmmade pig feed mixtures by NIR-spectroscopy.] 103th VDLUFA-Kongress, Ulm, 4 pp.

Scotter, C. N. G. (1993). Recent advances and applications for NIR in the food and drink manufacturing industries. In Proceedings of ADAS Drayton Feed Evaluation Unit Conference. NIRS Developments in Agriculture and Food, 10pp. Oxford: ADAS.

Shenk, J. S. (1992). NIRS analysis of natural agricultural products. In Near Infra-red Spectroscopy. Bridging the Gap between Data Analysis and NIR Applications, pp. 235-240 [K. I. Hildum, T. Isaksson, T. Næs and A. Tandberg, editors]. London: Ellis Horwood. 
Shenk, J. S. (1995). NIRS technology for the feed industry. Presentation at the Seminar for the Feed and Agricultural Industry, Gent, Belgium, 9 pp.

Shenk, J. S., Hoover, M. R. \& Westerhaus, M. O. (1979). Infrared analysis of forages and feeds. Proceedings of the Maryland Nutrition Conference for Feed Manufacturers, 96-101.

Shenk, J. S. \& Westerhaus, M. O. (1991). Population definition, sample selection and calibration procedures for near infrared reflectance spectroscopy. Crop Science 31, 469-474.

Shenk, J. S., Workman, J. J. \& Westerhaus M. O. (1992). Application of NIR spectroscopy to agricultural products. In Handbook of Near-Infrared Analysis, pp. 383-431 [D. A. Burns and E. W. Ciurczak, editors]. New York: Marcel Dekker.

Snyman, L. D, \& Joubert, H. W. (1992). Near infrared reflectance analysis of the fermentation characteristics of silage prepared by chemical treatment to prevent volatilisation of fermentation end products. Animal Feed Science and Technology 37, 47-58.

Starr, C., Sutte J., Morgan, A. G. \& Smith, D. B. (1985). A comparison of sample preparation and calibration techniques for the estimation of nitrogen, oil and glucosinolate content of rapeseed by near infrared spectroscopy. Journal of Agricultural Science 104, 317-323.

Steen, R. W. J., Gordon, F. J., Mayne, C. S., Agnew, R. E., Unsworth, E. F., Kilpatrick, D. J., Barnes, R. J., Porter, M. G. \& Pippard, C. J. (1995). Prediction of silage intake by cattle. Animal Science 60, 514 (Abstr).

Tremblay, G. F., Broderick, G. A. \& Abrams, S. M. (1996). Estimating ruminal protein degradability of roasted soybeans using near infrared reflectance spectroscopy. Journal of Dairy Science 79, 276-282.

Valdes, E. V. \& Leeson, S. (1992). Near infrared reflectance analysis as a method to measure metabolizable energy in complete poultry feeds. Poultry Science 71, 1179-1187.

Valdes, E. V., Young, L. G., Leeson, S., McMillan. I., Portela, F. \& Winch, J. E. (1985). Application of near infrared reflectance spectroscopy to analyses of poultry feeds. Poultry Science 64, 2136-2142.

Van der Meer, J. M., Vedder, H. \& Wever, G. (1988). NIRS for the prediction of organic matter and energy digestibility in pig feeds. In Vitro Newsletter 4, 25-26.

Van Kempen, T. \& Jackson, D. (1996). NIRS may provide rapid evaluation of amino acids. Feedstuffs 68 (50), 12-15.

Van Leeuwen, P., Verstegen, M. W. A., van Lonkhuijsen, H. J. \& van Kempen, G. J. M. (1991). Near infrared reflectance (NIR) spectroscopy to estimate the apparent ileal digestibility of protein in feedstuffs. In: Digestive Physiology in Pigs (International Symposium 5; EAAP Publication no. 54), pp 260-265 [M. W. A. Verstegen, J. Huisman \& L. A. den Hartog, editors]. Wageningen, The Netherlands: Pudoc.

Van Lonkhuijsen, H. J. \& Jansen, H. D. (1987). [Fast Weende analysis of compound feeds by NIRS.] De Molenaar 90. 1505-1515.

Varadi, M. (1991). Near infrared reflectance spectroscopy for meat. In Food Technology International Europe, pp. 123128. [A. Tumer, editor]. London: Sterling Publications.

Vejgaard, L., Jacobsen, E. E. \& Jensen, E. P. (1987). [Development of NIR techniques for feed companies.] Bererning no. 138 of Bioteknisk Institut, 135 pp. Kolding, Denmark.

Verheggen, J., Dardenne, P., Théwis, A. \& Biston, R. (1990). Application of near infrared reflectance spectroscopy (NIRS) for predicting chemical composition, cellulose digestibility of organic matter and energy values of compound feedstuffs for ruminants. In Proceedings of the Third Intemational Conference on Near Infrared Spectroscopy, pp. 287-290 [R. Biston and N. Bartiaux-Thill, editors]. Gembloux, Belgium: Agricultural Research Centre.

Ward, R. G., Smith, G. S., Wallace, J. D., Urquhart, N. S. \& Shenk, J. S. (1982). Estimates of intake and quality of grazed range forage by near infrared reflectance spectroscopy. Journal of Animal Science 54, 399-402.

Waters, C. J. \& Givens, D. I. (1992). Nitrogen degradability of fresh herbage. Effect of maturity and growth type, and prediction from chemical composition and by near infrared reflectance spectroscopy. Animal Feed Science and Technology 38, 335-349.

Weisbjerg, M. R. \& Hvelplund, T. (1993). [Estimation of net energy content (FU) in feeds for cattle.] Report no. 3 from the National Institute of Animal Science, Tjele, Denmark, $39 \mathrm{pp}$.

Welch, R. (1988). Oats for human food. In A Review of the Potential for the Production and Utilisation of Oats in the United Kingdom, pp. 14-36 [R. M. Bennett, editor]. Centre for Agricultural Strategy, Reading.

Williams, P. C. (1975). Application of near infrared reflectance spectroscopy to analysis of cereal grains and oilseeds. Cereal Chemistry 52, 561-576.

Williams, P. C. \& Cordeiro, H. M. (1985). Effect of calibration practice on correction of errors induced in near infrared protein testing of hard red spring wheat by growing location and season. Joumal of Agricultural Science 104, $113-123$.

Williams, P. C., Cordeiro, H. M. \& Harnden, M. F. T. (1991). Analysis of oat bran products by near infrared reflectance spectroscopy. Cereal Foods World 36, 571-574.

Williams, P. C. \& Nomis, K., editors (1990). Near-Infrared Technology in the Agricultural and Food Industries. Minnesota: American Association of Cereal Chemists, 330 pp.

Williams, P. C., Preston K. R., Norris, K. H. \& Starkey, P. M. (1984). Determination of amino acids in wheat and barley by near-infrared reflectance spectroscopy. Journal of Food Science 49, 17-20.

Williams, P. C. \& Sobering D. (1992). Whole-seed grain analysis by near-infrared transmittance and reflectance: a comparison. In Near Infrared Spectroscopy. Bridging the Gap between Data Analysis and NIR Applications, pp. 441-446 [K. I. Hildrum, T. Isaksson, T. Næs and A. Tandberg, editors]. London: Ellis Horwood.

Williams, P. C. \& Starkey, P. M. (1980). Influence of feed ingredients upon the prediction of protein in animal feedmixes by near-infrared reflectance spectroscopy. Journal of the Science of Food and Agriculture 31, 1201-1213. 